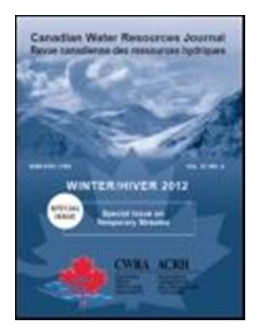

\title{
3D hydrostratigraphical modelling of the regional aquifer system of the St. Maurice Delta Complex (St. Lawrence Lowlands, Canada)
}

\begin{tabular}{|r|l|}
\hline Journal: & Canadian Water Resources Journal \\
\hline Manuscript ID & TCWR-2016-0059.R2 \\
\hline Manuscript Type: & Original Paper \\
\hline Complete List of Authors: & $\begin{array}{l}\text { Légaré-Couture, Guillaume; Institut national de la recherche scientifique, } \\
\text { Centre Eau Terre Environnement } \\
\text { Leblanc, Yves; Universite du Quebec a Trois-Rivieres, Environmental } \\
\text { Sciences } \\
\text { Parent, Michel; Commission géologique du Canada, Ressources naturelles } \\
\text { Canada } \\
\text { Lacasse, Karine; Université du Québec à Trois-Rivières, Environmental } \\
\text { Sciences } \\
\text { Campeau, Stephane; Universite du Quebec a Trois-Rivieres, Environmental } \\
\text { sciences }\end{array}$ \\
\hline Keywords: & $\begin{array}{l}\text { Granular aquifers, Quaternary deposits, 3D geological modelling, High } \\
\text { resolution seismic reflection, Champlain Sea }\end{array}$ \\
\hline
\end{tabular}

\section{SCHOLARONE ${ }^{\text {M }}$}

Manuscripts 
1 3D hydrostratigraphical modelling of the regional aquifer system of the

2 St. Maurice Delta Complex (St. Lawrence Lowlands, Canada)

3 Guillaume Légaré-Couture ${ }^{1}$, Yves Leblanc ${ }^{2}$, Michel Parent ${ }^{3}$, Karine Lacasse ${ }^{2}$ and

4 Stéphane Campeau ${ }^{4}$

1 Institut national de la recherche scientifique, Centre Eau Terre Environnement, Québec City, Québec, Canada, G1K 9A9, Guillaume.Legare-Couture@ete.inrs.ca

2 Département des sciences de l'environnement, Université du Québec à Trois-Rivières, Trois-Rivières, Québec, G9A 5H7, yves1@sympatico.ca,

Karine.Lacasse@mrc-maskinonge.qc.ca

3 Commission géologique du Canada, Ressources naturelles Canada, Québec, G1K 9A9, michel.parent@canada.ca

4 Corresponding author : Département des sciences de l'environnement, Université du Québec à Trois-Rivières, Trois-Rivières, Québec, G9A 5H7, 819-376-5011, Stephane.Campeau@uqtr.ca

For the use of the editors

Paper \#: TCWR-2016-0059.R2

Submitted on: October 14, 2016

Accepted on: April 3, 2017

Application - Research - Commentary - Book Review: Research (QC GW SI)

Copyright Held by: CWRA

\section{T2012}


In the central part of the St. Lawrence Lowlands (Mauricie, Québec), Late 20 Quaternary deglacial events led to the formation of a series of complex granular aquifers, 21 such as those in the 1) Saint-Narcisse morainic complex, 2) paleodelta formed by the 22 Saint-Maurice River, and 3) sandy littoral terraces left during marine regression. The 23 aquifers are an important supply of potable water for most municipalities in the region, 24 including the City of Trois-Rivières, which is a mid-size city where groundwater 25 accounts for $46 \%$ of the water supply. The main objectives of this study were to build a 26 3D model of the Quaternary deposits to define the main hydrogeological contexts of the 27 Mauricie region and to characterize the regional aquifers. The compilation of existing 28 hydrogeological data led to the selection of 5386 well logs that contained stratigraphic 29 information of variable quality, ranging from only surficial sediment thickness to 30 descriptions of fully cored boreholes. To supplement the existing data, fieldwork was 31 undertaken in areas where few data were available, including $63 \mathrm{~km}$ of high resolution 32 seismic reflection surveys and 34 new boreholes. The final 3D model consists of six 33 layers, from the bedrock surface to the upper littoral and deltaic sands. The total thickness 34 of the deposits ranges from zero, on bedrock outcrops, to $150 \mathrm{~m}$ beneath central Trois35 Rivières. Taking into account the thickness of the saturated layer and the porosity of the 36 sand and gravel, the upper unconfined aquifer contains an estimated 364 million $\mathrm{m}^{3}$ of 37 water. The 3D model helped refine our understanding of regional aquifers and was used 38 to identify unexploited aquifers, notably around the Saint-Narcisse morainic complex and 39 along the St. Cuthbert Fault. The model clarified the regional stratigraphic architecture, 40 especially topography of the bedrock surface, the lateral extent of Late Quaternary sands 41 and development of Holocene post-glacial sediment sequences.

42 Keywords : Granular aquifers, Quaternary deposits, 3D geological modelling, High reso43 lution seismic reflection, Champlain Sea 


\section{Résumé}

Dans la partie centrale des Basses-Terres du Saint-Laurent (Mauricie, Québec), la

46 dernière déglaciation a mené à la formation d'aquifères granulaires complexes, tels que

47 ceux associés à la moraine de Saint-Narcisse, au paléodelta de la rivière Saint-Maurice et

48 aux terrasses littorales associées à la régression marine. Ces aquifères représentent la

49 source principale d'eau potable pour la majorité des municipalités de la région, incluant

50 Trois-Rivières, une ville de taille moyenne où les eaux souterraines contribuent à $46 \%$ de

51 l'approvisionnement. L'objectif de cette étude était de développer un model 3D des

52 dépôts quaternaires afin de définir les principaux contextes hydrogéologiques et de

53 caractériser les aquifères régionaux de la Mauricie. Le recensement des données

54 hydrogéologiques existantes a permis de compiler les résultats de 5386 puits et forages

55 contenant des informations stratigraphiques de qualité variable. Les données existantes

56 ont été complétées par de nouveaux relevés, incluant $63 \mathrm{~km}$ de sismique réflexion haute

57 résolution et 34 forages. Le model 3D final est constitué de sept couches, de la surface du

58 rock aux sables littoraux et deltaïques superficiels. L'épaisseur total des sédiments

59 quaternaires varie de nulle sur les affleurements rocheux à $150 \mathrm{~m}$ à l'ouest de la ville de

60 Trois-Rivières. Le volume total des sables superficiels, dans les limites de la ville de

61 Trois-Rivières, a été estimé à 4.7 milliards de $\mathrm{m}^{3}$. En tenant compte de l'épaisseur de la

62 zone saturée et de la porosité moyenne du sable, la nappe libre contiendrait un volume de

63364 millions de $\mathrm{m}^{3}$ d'eau. Le model tridimensionnel a permis d'approfondir notre

64 connaissance des aquifères régionaux et d'identifier des aquifères non exploités,

65 notamment en marge de la moraine de Saint-Narcisse et le long de la faille de St-

66 Cuthbert. Le model a également permis de préciser l'architecture des dépôts et la

67 stratigraphie régionale, particulièrement en ce qui concerne la topographie de la surface

68 du rock, l'extension latérale des dépôts pléistocènes et la séquence des sédiments

69 postglaciaires.

\section{Introduction}

71 The current landscape of the St. Lawrence Valley is mainly the result of erosion

72 and deposition during successive Late Quaternary events. Deglaciation was followed by a 
73 2000-year long incursion of an arm of the Atlantic Ocean into the St. Lawrence, known 74 as the Champlain Sea. During this marine episode, a series of coastal, deltaic and 75 offshore depositional systems developed in the valley. Following the regression of the 76 Champlain Sea and the drainage of its successor basin (Lake Lampsilis), fluvial incision, 77 sedimentation and terrace formation by the early St. Lawrence River and its tributaries 78 became the main centres for active geological processes in the valley. Elsewhere in the 79 region, this late-glacial period was characterized by the development of peatlands, 80 notably on the large flat surfaces of the St. Maurice paleodelta.

81 The last deglacial events led to the formation of a series of complex granular 82 aquifers, such as the Saint-Narcisse morainic complex, the Saint-Maurice River 83 paleodelta, and the stepped sandy terraces formed along the shores of the Champlain Sea 84 and along the St. Lawrence River and tributaries. The characteristics and distribution of 85 these aquifers are partially known through various hydrogeological studies conducted by 86 municipalities, government agencies and private consulting firms. Unfortunately, these

87 studies had limited application regionally because they were generally local in scope and 88 scale. The first regional groundwater map of the Mauricie region was constructed by

89 McCormack (1983), who noted the good aquifer potential of the surficial and near

90 surface sediments of the north shore, while the aquifer potential of fractured bedrock was

91 deemed lower. While he identified buried valleys filled with sand and gravel deposits, he

92 had not evaluated the hydrogeological potential of these confined aquifers. In the nearby

93 Lake Maskinongé area, Denis (1974) also mentioned that the bedrock formations of the

94 region had a low aquifer potential, while the granular aquifers were more important.

95 Nonetheless, and despite these preliminary attempts to map the local aquifers, there still

96 lacks comprehensive knowledge of the different hydrogeological units and their surface

97 or subsurface distribution. Given the crucial importance of groundwater as a source of

98 potable water in the region, both from quality of life and economic viewpoint, we

99 determined that a more thorough characterization and assessment of regional aquifers

100 was needed.

101 Groundwater has been exploited in the Mauricie region since the nineteenth 102 century to supply municipal water networks and for commercial purposes. In the town of 
103 Yamachiche, for example, an aqueduct was built in 1873 to extract spring water

104 renowned for its high quality. In the early twentieth century, a brackish water source

105 located in Saint-Léon-Le-Grand became known for its healing properties. Nowadays, the

106 granular aquifers of the Mauricie region are the source of potable water for most of its

107 municipalities, including the City of Trois-Rivières, which is one of few small urban

108 centers in Canada where groundwater constitutes a large part of the drinking water supply

109 (46\%). In addition, the use of geothermal energy for heating and cooling has expanded

110 during the last decade. Given the relatively high groundwater temperature $\left(10^{\circ} \mathrm{C}\right.$ in Trois-

111 Rivières) and the high aquifer potential of the region, it is likely that geothermal systems

112 will continue to expand rapidly in the near future to capture thermal energy from the

113 warmer groundwater.

114 Given the lack of comprehensive knowledge about the regional aquifers and the 115 crucial role of groundwater in the Mauricie region, a regional groundwater study was 116 initiated by Université du Québec à Trois-Rivières (UQTR) researchers in collaboration

117 with governmental agencies and regional partners (including the regional council of

118 elected officials, regional municipalities, the City of Trois-Rivières and watershed

119 agencies). The study was conducted between 2009 and 2013 as part of the Groundwater

120 Knowledge Acquisition Program (PACES), sponsored by the Quebec Ministry of the

121 Environment (MDDELCC). One of the main objectives of this study was to build a 3D

122 model of Quaternary deposits to better define the hydrogeological framework for the

123 Mauricie region and characterize the aquifer properties.

\section{Study area}

125 The study area $\left(3900 \mathrm{~km}^{2}\right)$ is located in the southwest of the Mauricie region, between

126 Montréal and Québec (Figure 1). The total population (2011) is 223200 inhabitants, distributed into

127 two main urban centers (Trois-Rivières and Shawinigan) and one regional municipality

128 (Maskinongé). The northern part of the study area lies in the Laurentian Hills, and is mostly

129 forested, whereas the southern part is underlain by the relative flat terrain of St. Lawrence platform

130 and is occupied by farmlands, except for the urban area of Trois-Rivières. The shield terrain of the

131 Laurentians is characterized by steep-sided knolls and knobs, intersected by linear through-valley 
132 systems, often occupied by chains of lakes and logging roads, while the St. Lawrence platform is

133 underlain by Paleozoic sedimentary rocks covered by thick Quaternary sediments, where

134 agriculture is the main economic activity. The main rivers (Maskinongé, du Loup, Yamachiche and

135 St. Maurice) flow southward from the Shield terrain to the lowlands. The hydrological regime of

136 these catchments is characterized by spring snowmelt and low flow during summer with episodic

137 storm events, typical of continental sub-humid, subpolar climates. Catchments receive between 850

138 and $1200 \mathrm{~mm}$ of precipitation annually, evenly distributed during the year.

139 Figure 1. Location and digital elevation model of the study area. The four main 140 regional hydrogeologic contexts are shown: the Laurentian Hills, Saint-Narcisse morainic complex, Marine clay plain and paleodelta of the St. Maurice River.

First, a compilation map of bedrock formations was realized as part of this project, based on

143 the studies conducted by Clark et Globensky (1976), Globensky (1987) and Nadeau and Brouillette

144 (1995). The lithological composition of the Grenville Province, a major subdivision of the Canadian

145 Shield, consists mainly of igneous and metamorphic rocks, such as gneiss, orthogneiss, paragneiss,

146 migmatite and marble, along with intrusive rocks such as gabbronorite, anorthosite, monzonite and

147 monzogranite. The Grenville rocks are moderately folded in the allochthonous monocyclic belt and

148 strongly folded in the polycyclic belt. The rocks of the Morin Terrane, in the south and west of the

149 study area, were slightly deformed during the Grenville orogeny to form a large regional syncline.

150 The sedimentary rocks of the lowlands consist mainly of Ordovician sandstones,

151 limestones and shales deposited in marine environments. Sandstones and limestones (Black River

152 and Trenton groups) are exposed in isolated outcrops in the northern part of the lowlands, while the

153 shales (Utica and Lorraine groups) are buried under considerable thicknesses of Quaternary

154 sediments near the St. Lawrence River. These shales contain significant concentrations of natural

155 gas as well as oil seeps and have been fully described in geological reports (Globensky, 1987). The

156 fractured bedrock aquifers, both in the shield and the lowlands, only supply private wells.

Secondly, an updated map of surficial deposits was constructed (Figure 2) based on results

158 of previous studies by Denis (1974), Bolduc (1999a, b) and Lamarche (2005). The

159 Laurentian Hills are characterized by a thin till veneer with numerous rock exposures.

160 Along the southern edge of this hilly region, valleys are floored by silty or silty-sandy 
161 marine sediments that commonly overlie ice-proximal sandy gravels that are buried. The

162 Saint-Narcisse Moraine lies along the southern margin of the Canadian Shield, but

163 slightly beyond in the St. Maurice River valley. The moraine was emplaced by a re-

164 advance of the Laurentide Ice Sheet during the early cold phase of the Younger Dryas. In

165 stratigraphic sections in the moraine, a variety of sediment facies, including glacially

166 entrained clay and till wedges, are exposed along with proximal glaciomarine deposits,

167 melt-out till and ice-marginal outwash (Occhietti, 2007). As the Laurentide Ice Sheet

168 retreated to the north, the Champlain Sea flooded the Saint Lawrence Valley up to almost

$169200 \mathrm{~m}$ asl, an event that led to the deposition of a thick silt and clay cover in the deeper

170 offshore basins and littoral and sublittoral sands in shallower areas. Deltas, large and

171 small, also formed in valleys at the mouth or rivers entering the Champlain Sea.

172 Figure 2. Quaternary geology and location of the new geophysical surveys and

173 boreholes. The location of the existing boreholes and wells $(5386)$ used to build the

174 model are not shown. See Table 2 for a detailed description of the units.

175 The Quaternary stratigraphy of the area was described by Gadd and Karrow

176 (1959), Denis (1974), Occhietti (1980, 2007), Ferland and Occhietti (1990) and Clet and

177 Occhietti (1996). The most complete stratigraphic sections were observed along the St.

178 Maurice River. The base of the Quaternary sequence is characterized by a fluvial

179 sediment complex directly overlying bedrock. This unit is correlated with the Lotbinière

180 Sand (Hardy and Lamothe, 1997), rather than the St. Pierre Sediments as originally

181 thought by Gadd and Karrow (1959). The overlying unit, containing a nine meter-thick

182 varve series, is known as the St. Maurice Rhythmites since it corresponds to a lacustrine

183 environment younger than that of the Deschaillons Varves (Besré and Occhietti, 1990).

184 The rhythmites are overlain in the regional stratigraphic record by the stratified Vieilles-

185 Forges Sands, with three lithozones (lacustrine, deltaic and proglacial). This sequence is

186 capped by the Gentilly Till, which is in turn overlain by the usual postglacial sequence

187 containing glaciofluvial sediments, Champlain Sea sediments, Lake Lampsilis sediments,

188 and alluvial and organic sediments (Table 2). 


\section{Compilation of existing boring data}

191 Existing hydrogeological data were compiled from the sources presented in Table

192 1. All the municipalities in the study area were visited to obtain existing hydrogeological

193 studies. The databases from the major water supply providers were integrated, including

194 those from the cities of Trois-Rivières and Shawinigan and from a regional water supply

195 network (Régie d'Aqueduc de Grand-Pré). The compilation of existing hydrogeological

196 data led to the selection of $5386 \operatorname{logs}$ for the modelling that contained some stratigraphic

197 information. Among these entries, 2185 reached bedrock and 3201 ended within

198 Quaternary sediments. The reliability of the existing data was evaluated based on the

199 criteria proposed by Ross et al. (2005) and Chesnaux et al. (2011), and hydrostratigraphic

200 codes were assigned to each entry in the database. When available, the hydraulic

201 properties were integrated to the database.

\section{Field work}

203 To supplement the existing data, fieldwork was undertaken in areas where data were

204 sparse or the stratigraphic interpretations were uncertain (Figure 2). The new fieldwork 205 included:

- 75 electrical resistivity surveys (using a TX-II transmitter and PP GRX-832 receiver). The interpretations were validated with borehole logs located within $500 \mathrm{~m}$ of the survey line;

- 50 seismic refraction surveys (using a Smartseis ST with 24 geophones);

- $63 \mathrm{~km}$ of high resolution seismic reflection surveys (using the Minivibe);

- 11 cone penetration tests (using a Geotech 605D);

- 23 boreholes were drilled by different techniques (rotation, percussion, pionjar and rotasonic). Monitoring wells were installed in most of the boreholes. The sediments were sampled at regular intervals or at the transition between two stratigraphic units. Particle size analysis (Analysette 22 MicroTec) was carried out on 425 samples. The hydraulic conductivity of each sample was estimated 
from the grain size analysis. Radiometric dating (Beta Analytic Inc) was conducted on three samples of shells or organic material. Water level measurements and pumping tests were carried out in most wells.

Finally, the detailed Quaternary geology mapping was carried out throughout the region, but more specifically in areas along the boundary of maps created by different authors. The data collected in the field allowed us to produce a relatively uniform compilation map of surficial sediments for the study area.

\section{Geostatistical modelling approach}

Cokriging was used to create gridded surfaces connecting the logs according to the elevation of stratigraphic contacts. This method of geostatistical estimation considers the spatial covariance and assigns a different weight to the observations based on their reliability. A digital elevation model (DEM) was used to determine the elevation of all borehole sites included in the database. The model also considered the outcrops of all deposits and the known stratigraphy shown on geological sections. Additionally, some adjustment points were manually added to the model at locations where available data were either insufficient or inadequate. For example, the range of the variogram was sometimes insufficient to properly interpolate grid values up to the boundaries of the

234 study area and some adjustment points were added to fill in the void. The adjustment

235 point were not included in the calculation of the error for each layer. Virtual sections

236 were also generated using Hydro GeoAnalyst software to link, at the regional scale,

237 similar facies where data are sparse or widely spaced (Ross et al. 2005). A final

238 validation was performed to check whether the model-generated layers were contained in

239 the volume between the rock surface and the ground surface. Figure 3 shows the

240 flowchart of the GIS operations used to model the top surface of each hydrogeological 241 unit. hydrogeological unit. 


\section{Results}

245 Three-dimensional mapping of Quaternary deposits

246 The model consists of seven layers representing the topography of the bedrock

247 surface and the main hydrogeological units encountered in the study area. Because the

248 model is being constructed at a regional scale, some units were merged with other in

249 order to give precedence to the more extensive and thicker aquifers and aquitards.

250 Topography of the bedrock

251 A total of 1584 observations from boreholes and geophysical data were used to 252 model the surface of the bedrock. Before the addition of adjustment points, the root mean 253 squared error between the observed and predicted values was $5.0 \mathrm{~m}$. In addition, 484

254 bedrock outcrop areas were used as control to model the bedrock surface.

In the lowlands, near the St. Lawrence River, the smooth bedrock surface lies as 256 much as $100 \mathrm{~m}$ below present sea level. However, the bedrock surface rises to the north257 east of the St. Maurice River and on the south shore of the St. Lawrence River. On a 258 south-north axis, the bedrock surface rises slowly northwestward toward the Piedmont, 259 except along the St. Cuthbert Fault, which is the locus of a NE-trending linear depression 260 in bedrock. The maximum elevation of 540 masl is reached in the Laurentian Hills, north 261 of the municipality of Saint-Alexis-des-Monts.

262 Figure 4 shows the total thickness of Quaternary deposits. This map was produced 263 by subtracting the elevation of the DEM surface from the elevation of the bedrock

264 surface. The thickest deposits reach $150 \mathrm{~m}$ in the western part of the City of Trois-

265 Rivières where the bedrock surface lies at $-80 \mathrm{~m}$, an elevation which is quite similar to 266 that underneath Yamachiche and which is amongst the lowest of the entire central St.

267 Lawrence Lowlands (Prévôt, 1972).

268 Figure 4. Total thickness of Quaternary deposits. The thickest deposits, reaching 269 $150 \mathrm{~m}$, are in the western part of the City of Trois-Rivières. 
Pleistocene sediments deposited prior to the Last Glacial Maximum (LGM) have been observed in sections bordering the St. Maurice River and were also intersected by

273 drilling in the southeast part of the study area. A total of 85 observations from boreholes

274 and geophysical data were used to model the upper contact of pre-LGM sediments

275 (Figures 5a and 6a). Before the addition of adjustment points, the root mean squared error

276 between the observed and predicted values was $8.6 \mathrm{~m}$. In addition, 3 surficial outcrops

277 were used to control the modeled surface. Reliable drilling logs containing descriptions

278 of the unit were only found around the City of Trois-Rivières, where the maximum

279 thickness of the unit is $80 \mathrm{~m}$. However, it is possible that other remnants of pre-LGM

280 Quaternary sediments are preserved elsewhere in the region. Given their rare occurrence

281 in drilling record, no attempt was made to model separately the different pre-LGM

282 sediment subunits in the 3D hydrostratigraphical model. However, some pre-LGM

283 subunits could be identified in high resolution seismic profiles. These deposits are

284 discontinuous and their thickness varies depending on the topography of the bedrock 285 surface.

Figure 5. 3D model of Quaternary deposits. The model consists of six layers representing the main hydrogeological units observed above bedrock in the study area. The six layers represent the Pleistocene sediments (pre-LGM) (a), LGM and post-Younger Dryas tills (b), glaciofluvial sediments (c), marine silt and clay (d), St. Narcisse morainic complex (e) and littoral, deltaic and alluvial sediments (f).

Figure 6. Thickness grids (m) of Quaternary deposits.

295 Wisconsinan glaciation. In the context of this paper, it includes diamictons that were

296 deposited during and after the St-Narcisse Moraine episode. Gentilly Till is a sandy-silt 
297 diamicton having a Precambrian crystalline rock content ranging from $100 \%$ in the Shield

298 terrains to less than $10 \%$ on the Paleozoic platform. A total of 162 observations from

299 boreholes and geophysical data were used to model the upper contact of Gentilly Till

300 (Figures $5 \mathrm{~b}$ and $6 \mathrm{~b}$ ). Before the addition of adjustment points, the root mean squared

301 error between the observed and predicted values was $3.6 \mathrm{~m}$. In addition, 241 surficial

302 polygons were used to model the surface of the unit.

303 In the Laurentians, the glacial till cover is discontinuous and its thickness varies

304 from $0.1 \mathrm{~m}$ to $2 \mathrm{~m}$. However, the till can be $6 \mathrm{~m}$ thick where mapped as continuous cover.

305 Along the St-Narcisse Moraine, the till thickness varies between $1 \mathrm{~m}$ and $50 \mathrm{~m}$. In

306 drilling records around the moraine, till wedges (thrust slices in most cases) deposited by

307 the advancing ice sheet are difficult to differentiate from glaciofluvial sediment bodies

308 emplaced subsequently and commonly reworked by littoral Champlain Sea processes.

309 South of the moraine, in the clay plain, the till usually takes the form of a veneer varying

310 in thickness depending on the topography of the bedrock surface.

\section{Glaciofluvial sediments}

312 Sediments carried by glacial meltwater were deposited in the deep valleys of the

313 Canadian Shield and in bedrock depressions along the St. Cuthbert Fault. In the northern

314 part of the study area, at elevations above $200 \mathrm{~m}$ asl, these sediments are well exposed at

315 the surface, while in very deep valleys and on the Shield margins, they are almost

316 continually covered with fine-grained sediments of marine or lacustrine origin. A total of

317341 observations from boreholes and geophysical data were used to model the upper

318 contact of glaciofluvial sediments (Figures 5c and 6c). Before the addition of adjustment

319 points, the root mean squared error between the observed and predicted values was $2.6 \mathrm{~m}$.

320 In addition, 117 sediment surface polygons were used to control the modeled surface.

321 The largest thicknesses were observed under the deep valleys of the Canadian Shield,

322 under the St-Narcisse Moraine and along the St. Cuthbert Fault.

\section{Marine silt and clay}


As the St. Lawrence valley had been isostatically depressed by the Laurentide Ice Sheet, an arm of the Atlantic Ocean, known as the Champlain Sea, inundated the valleys up to elevations equivalent to $200 \mathrm{~m}$ asl (Parent et Occhietti, 1988, 1999). The marine transgression lasted about 2500 years (between 13 cal ka BP to $10.5 \mathrm{cal} \mathrm{ka} \mathrm{BP}$ ), and the incursion was characterized by the deposition of thick, sparsely fossiliferous marine clays. Around $9.8 \mathrm{ka} \mathrm{BP}$, marine waters gradually drained due to the isostatic rebound and saltwater was replaced by freshwater (Lake Lampsilis). With continued isostatic adjustment, as well as reduced meltwater influx to the basin, Lake Lampsilis was gradually drained by the Proto St. Lawrence River (7.5 cal ka BP to 3.0 cal ka BP).

A total of 2287 observations from boreholes and geophysical data were used to model the upper contact of marine and lacustrine sediments (Figures $5 \mathrm{~d}$ and $6 \mathrm{~d}$ ). Before

335 the addition of adjustment points, the root mean squared error between the observed and

336 predicted values was $5.1 \mathrm{~m}$. In addition, 118 sediment surficial outcrops were used to

337 control the modeled surface. Marine and lacustrine sediments overlie till and glaciofluvial

338 sediments in the major valleys of the Canadian Shield, as well as most of the St.

339 Lawrence Lowlands. The thickest units of fine-grained sediments are located around the

340 municipalities of Yamachiche and Louiseville, where more than $80 \mathrm{~m}$ of silt and clay are

341 recorded in the drilling records. These maximum thicknesses are controlled by a

342 depression in the bedrock around Lake St. Pierre (Prévôt, 1972). In the paleodelta of the

343 St. Maurice River, the thickness of subsurface silty clay sediments varies from 0 to $30 \mathrm{~m}$.

\section{St. Narcisse morainic complex}

345 The Saint-Narcisse morainic complex was emplaced during a re-advance of the

346 Laurentide Ice Sheet from 12.9 to $12.5 \mathrm{cal}$ ka BP, along the southern margin of the

347 Laurentians where it forms a $750 \mathrm{~km}$ long crest (Occhietti, 2007). From west to east, the

348 moraine successively covers the Precambrian bedrock and then fine-grained Champlain

349 Sea sediments in the St. Maurice valley. The moraine forms prominent ridges near

350 Charette and Mont-Carmel. The moraine is composed of reworked clay and till, proximal

351 glaciomarine deposits and melt-out till and ice-marginal outwash (Occhietti, 2007). 
A total of 75 observations from boreholes and geophysical data were used to

353 model the upper contact of the St. Narcisse morainic sediments (Figures 5e and 6e).

354 Before the addition of adjustment points, the root mean squared error between the

355 observed and predicted values was $7.5 \mathrm{~m}$. In addition, 41 sediment outcrop polygons

356 were used to control the modeled surface. In the Lower Mauricie region, the composition

357 of the morainic complex varies widely, but generally it consists of gravel, coarse sand

358 and poorly sorted medium sands deposited above a layer of marine sediments. The

359 thickness of this layer of coarse sediments varies from 10 to $50 \mathrm{~m}$.

360 Littoral, deltaic and alluvial sediments

361 During the Holocene, the retreat of the ice sheet was accompanied by regional 362 isostatic uplift estimated at $9 \mathrm{~m} / 100$ years (Lamarche, 2005). The Champlain Sea was 363 replaced by Lake Lampsilis, a freshwater successor basin that lasted about 1500 years.

364 The present drainage system was gradually emplaced, thus creating successive terrace

365 levels as base levels fell. The modeled layer that represents the surface sands includes (1)

366 all sand units overlying fine-grained Champlain Sea sediments, including coastal and

367 deltaic silty sands, (2) lacustrine sands and silts of Lake Lampsilis, and (3) marine and

368 lacustrine deltaic sands of the St. Maurice River (Figures $5 \mathrm{f}$ and $6 \mathrm{f}$ ).

369 The upper sands are exposed at the land surface and therefore was not modeled 370 separately. The unit covers a total area of $1078 \mathrm{~km}^{2}$. The thickest areas of the surface 371 sand aquifer are located in the western and eastern sectors of the City of Trois-Rivières,

372 as well as in the localities of Sainte-Angèle-de-Prémont, Saint-Élie-de-Caxton and

373 Charette. In the Trois-Rivières area, the total volume of the upper aquifer is estimated at

3744.7 billion $\mathrm{m}^{3}, 31 \%$ of which is saturated according to our subsurface records. The unit

375 has an estimated porosity of $25 \%$, this means that about 364 million $\mathrm{m}^{3}$ of water are

376 contained in the unconfined aquifer. The aquifer has an average hydraulic conductivity of

$3776 \times 10^{-4} \mathrm{~m} / \mathrm{s}$. Groundwater generally flows toward southeast, its level ranging from $60 \mathrm{~m}$

378 upstream to $6 \mathrm{~m}$ at the outlet. Champlain Sea clays form the floor of the upper aquifer,

379 preventing groundwater from seeping further down through the Quaternary sequence. 
380 This aquifer is the most extensively exploited in the region and supplies drinking water to 381 about half of the population of the City of Trois-Rivières.

\section{Regional hydrogeologic contexts}

Based on the 3D model, the four main regional hydrogeologic contexts of the study area were determined from the physiographic, geological and hydrogeological

385 features (Figure 1). The hydraulic properties of the aquifers pertaining to each context are 386 presented in Tables 3 and 4.

\section{Laurentian Hills}

This hydrogeological context consists of fractured bedrock aquifers with low productivity (Table 4) along with granular aquifers within glaciofluvial deposits filling deep valleys. Up to an elevation of 200 masl, these deposits were covered by marine silts during the Champlain Sea marine transgression. Electrical resistivity surveys revealed over $60 \mathrm{~m}$ of silty clay in the Rivière-du-Loup Valley. Similar contexts were also encountered in the valleys of the Maskinongé, Yamachiche and Shawinigan rivers.

Elsewhere in the Laurentian Hills, deltaic sands and gravels were deposited by meltwaters at the mouths of major valleys entering the Champlain Sea. The glaciofluvial and deltaic deposits were reworked by waves and currents forming the high and low terraces along the piedmont. The aquifers found in these deposits are the main source of

398 potable water for most municipalities in the area.

The geologic log for borehole FE-04-11 (Figure 7), located in the village of Saint-

400 Élie-de-Caxton, illustrates this typical hydrostratigraphic complex. Directly overlying 401 granitic gneiss bedrock, at depth of $65.5 \mathrm{~m}$, Champlain Sea sediments from $109 \mathrm{~m}$ asl to $402140 \mathrm{~m}$ asl consist of ice-proximal sandy facies grading upward into a distal clay facies at $403134 \mathrm{~m}$ asl. The top layer consists of fine prodeltaic sands. 
underlying a clay or till aquitard resting on bedrock. These aquifers are relatively small

408 and hydraulically isolated from each other. Several electric resistivity surveys indicated

409 an overall thickness of over $60 \mathrm{~m}$. Borehole FE-09-11 is representative of this

410 hydrostratigraphic setting (Figure 7). The bedrock (garnet gneiss) was reached at a depth

411 of $87 \mathrm{~m}$. Overlying bedrock is a glaciofluvial unit consisting of sands (fine, medium and

412 coarse) and gravel, which is overlain by the Champlain Sea clays and silts from a depth

413 of 44 to $67 \mathrm{~m}$. The overlying units include a coarsening upward sequence of silty fine sand to

414 gravelly sand with a high hydraulic conductivity associated with the Saint-Narcisse readvance.

Figure 7. Logs of selected boreholes with lithology and grain size. The locations of the boreholes are shown in Figure 2.

The L1-2011 Minivibe line was run perpendicularly across the morainic complex

418 (Figure 8a). The line begins over Precambrian bedrock in the north, which is buried by

419 marine clays and thin beach sands. It passes over a narrow bedrock valley before crossing

420 the moraine (GxT) and entering the marine clay plain. The moraine is locally covered by

421 a thin layer of sand, and overlies heterogeneous glaciofluvial deposits. The glaciofluvial

422 sands and gravels rest on glaciotectonized clay and till wedges emplaced by the 423 advancing glacier.

424 Although the hydrostratigraphy of the moraine is complex, it contains an

425 important regional aquifer, as most of the small municipalities located along the moraine

426 and in the adjacent marine clay plain draw their drinking water from it. Moreover, the

427 moraine acts as a recharge area for the sandy surface aquifers connected to it. New

428 boreholes and geophysical surveys completed for this project revealed the presence of

429 double aquifers along the moraine that have yet been unexploited for a municipal water 430 supply.

431 Marine clay plain

432 The fine-grained sediments of the Champlain Sea sequences represent a regional

433 aquitard that confines the underlying aquifer unit containing groundwater with high

434 mineral content and natural gas. The aquifer potential of the clay plain is generally low. 
435 The municipalities of this area rely on a regional water supply network (Régie d'Aqueduc 436 de Grand Pré) whose wells are located near the foothills of the Laurentian Hills.

437 However, there are also a few private wells drawing water from the sandstone and 438 limestone bedrock.

The L7-9-2010 Minivibe lines (Figure 8b) are representative of the clay plain. In the south part, surficial sediments consist mainly of silt and clay ranging in thickness from 60-70 m, gradually decreasing further north. The underlying till becomes a thin

442 veneer over a partly buried rock ridge between kilometres 6 and 8.5. The bedrock surface

443 then plunges abruptly to form a depression two kilometres wide and 80 metres deep. The

444 buried depression appears to be filled with about 20 metres of gravel and sand. The

445 depression is covered by fine-grained marine sediments. This unit could potentially hold

446 significant quantities of groundwater. The axis of these deposits lie directly over the St.

447 Cuthbert Fault, which is a regional structure marking the boundary between Precambrian

448 Shield and sedimentary rocks of the Lowlands. It is possible that similar sand and gravel

449 aquifers are present elsewhere along the fault.

Figure 8. High resolution seismic survey lines L1-2011 (a) and L7-9-2010 (b). The profile interpretations are shown below the seismic profiles. See Figure 2 for location of the seismic lines and Table 2 for a detailed description of the units.

Paleodelta of the St. Maurice River

The paleodelta of the St. Maurice River is the largest aquifer in the region. The

455 delta forms a wide sand-dominated fan over a thin layer of silty marine sediments on the

456 east side of the river, and over a thick layer of pre-LGM deposits on the west side. Over

457 the northern part of the delta, the unconfined surficial aquifer is thin and is less

458 productive and not exploited, except for erosion channels where the sediment is thicker

459 and the sands better sorted. The surficial aquifer has a much greater thickness in the

460 southern part of the delta. Borehole FE-16-12 (Figure 7) contains almost $40 \mathrm{~m}$ of sand of

461 varying grain sizes. A wood sample found at $29.8 \mathrm{~m}$ depth in the upper delta surface was

462 dated at $8920 \pm 50$ BP (10.05 cal ka BP; Beta-318526). This date provides an age for the

463 beginning of the construction of the St-Maurice delta in the Champlain Sea. 
The aquifer is one source of drinking water for the greater Trois-Rivières area. A confined aquifer is also present below the marine clays, in pre-LGM sands (Vieilles-

466 Forges). However, data characterizing the aquifer are scarce. It is seldom as a water 467 source because the quality of groundwater is poor.

The L3-2010 and L3-2011 seismic lines were run parallel to the axis of the St.

469 Lawrence River (Figure 9). These profiles illustrate the transition from the deep water

470 depositional environment of the clay plain and the complex geology of the delta,

471 including the Lake Lampsilis sands, pre-LGM sediments and Gentilly Till. To the west of

472 the delta, the bedrock topography shows little variation, with a mean elevation of about -

$47350 \mathrm{~m}$ below sea level. The fine-grained sediments of the Champlain Sea fill the basin to a

474 thickness of $80 \mathrm{~m}$. The recent alluvial deposits of Lake Saint-Pierre cover the sequence

475 with $10 \mathrm{~m}$ of fine sands and silts. The light reflector observed in the marine sequence

476 could correspond to the Yamachiche Diamicton (Occhietti, 1980), which is a thin,

477 discontinuous coarse-grained deposit associated with the Saint-Narcisse Episode. The

478 sequence below the clay unit includes the Gentilly Till, Vieilles-Forges Sand, St. Maurice

479 Rythmites, Deschaillons Varves, and Lotbinière Sand. Only the first three units could be

480 differentiated from the drilling logs.

On the L3-2010 Minivibe line (Figure 9a), the till thickness varies from $4 \mathrm{~m}$ at the beginning of the section, to over $20 \mathrm{~m}$ at kilometer 1.4, where the Lotbinière Sand begins

483 to thin out. Champlain Sea silt and clay completely wedge out at km 2.8, where the sand

484 of the Champlain Sea-Lake Lampsilis succession rest directly on the till which rises to

485 shallow depths above the pre-LGM sediments. At this location, drilling indicates that pre-

486 LGM sediments constitute the largest part of the Quaternary column (over $80 \mathrm{~m}$ ).

The L3-2011 Minivibe line (Figure 9b) is the continuity of the preceding

488 sequence, about $1 \mathrm{~km}$ further south. The Champlain-Lampsilis sands are no longer

489 present and till is observed at the surface all along the $3 \mathrm{~km}$ long profile. The available

490 drilling logs allowed us to differentiate the Vieilles Forges Sand and the Saint-Maurice

491 Rythmites from the deeper and older Pleistocene sediments. 
Figure 9. High resolution seismic survey lines L3-2010 (a) and L3-2011 (b). The profile interpretations are shown below the seismic profiles. See Figure 2 for location of the seismic lines and Table 2 for a detailed description of the units.

To the east of the delta, a series of deltaic, lacustrine and alluvial sands form a vast aquifer with a thickness ranging from 11 to $35 \mathrm{~m}$. The aquifer overlies an impermeable clay (aquitard unit) with an average slope of the top surface coincident with the topography of the land surface (towards the SE). The aquifer is complex with significant vertical heterogeneity, containing interstratified medium to silty sand layers. The Quaternary deposits encountered in the borehole FE-02-11 (Figure 7) are $56.4 \mathrm{~m}$ thick and rest on the Ordovician sedimentary platform. Gentilly Till, identified at $38 \mathrm{~m}$ depth (-22 $\mathrm{m}$ below sea level), overlies a sequence of undifferentiated Pleistocene sediments that is $8 \mathrm{~m}$ thick. Champlain Sea clay overlies the till between 18 to $37 \mathrm{~m}$ depth. The uppermost unit, from 0 to $18.3 \mathrm{~m}$, consist of alluvial, littoral and deltaic sediments that were reworked by the fluctuating water levels of the St. Lawrence River. The base of this unit has been dated at $7.4 \mathrm{ka} \mathrm{BP}$ (8.2 cal ka BP; Beta-318525) on the basis of a wood fragment recovered at a depth of $14.5 \mathrm{~m}$. Since the alluvial unit from which the wood fragment was recovered marks the return to present-day conditions in the St. Lawrence River, Beta-31526 provides a maximum age for the end of delta construction. Taken together, the two ${ }^{14} \mathrm{C}$ dates indicated that the main part of the St-

\section{Hydrostratigraphic units}

513 The three-dimensional hydrostratigraphical model allowed the identification of four 514 main hydrostratigraphic units with a regional distribution:

- Unit 1: An aquifer within fractured bedrock, divided into three sub-units: 1) aquifer in crystalline rocks (with low fracture density) of the Precambrian basement; 2) aquifer in brittle sedimentary rocks (sandstones and limestones); and 3) aquifer in ductile sedimentary rocks (shales). This unit, while it has a regional extension, has a low potential for a water supply and is not being tapped by municipalities. 
- Unit 2: An aquifer in glaciofluvial and glacial sediments. This unit generally lies immediately above bedrock. The aquifers in glaciofluvial sediments, despite their small size and discontinuous areal distribution, supply a number of municipal wells. Till deposits, for their part, are thin and have a low permeability. However, water yields are generally sufficient to supply domestic wells.

- Unit 3: The regional discontinuous aquitard formed by fine-grained Champlain

7

$$
\text { Sea sediments. The deposits overlie almost continuously older Quaternary units in }
$$
the St. Lawrence Lowlands as well as in some isolated valleys or depressions of the Laurentian Hills.

- Unit 4: An aquifer formed in the uppermost sandy sediments. The unit can be divided into two sub-units: 1) sand and gravel deposits within the Saint-Narcisse morainic complex; and 2) surficial sand deposits overlying fine-grained sediments of the Champlain Sea, including coastal and deltaic silty sands, sands and silts of Lake Lampsilis and marine and lacustrine deltaic sands emplaced by the SaintMaurice River.
537 distribution of hydrogeological conditions lead us to define six aquifer types shown in 538 Figure 10:

- Type 1: Unconfined fractured bedrock aquifers, which may be locally overlain by $540 \quad$ a thin layer of till;

541 - Type 2: Confined or semi-confined fractured bedrock aquifers overlain by marine $542 \quad$ silt and clay (aquitard);

543 - Type 3: Unconfined aquifers in glaciofluvial sediments or littoral sands that lie 544 directly on the bedrock;

545 - Type 4: Double aquifers consisting of an upper, unconfined sandy aquifer and a $546 \quad$ confined or semi-confined aquifer in the fractured bedrock. These aquifers are $547 \quad$ separated by the regional aquitard;

548 - Type 5: Additional confined aquifers in glaciofluvial sediments that lie directly on 549 the bedrock and are overlain by marine silt and clay (aquitard). These units may $550 \quad$ lie underneath other units to form aquifer complexes. 
Figure 10. Aquifer types of the Mauricie region based on the architecture of the hydrostratigraphic units.

Figure 10 shows the distribution of the above aquifer types. Type 1 is the most

554 common aquifer in the Laurentian Hills, except in the valleys where types 2-5 are found,

555 such as the Saint-Alexis-des-Monts aquifer in the du Loup River valley. In the piedmont,

556 the Saint-Narcisse Moraine frequently contains types 4 and 5 aquifers, all hydraulically

557 separated from each other. The paleodelta of the St. Maurice River is an unconfined

558 aquifer of regional extent and has attributes of types 4 and 5. Only the upper, unconfined

559 aquifer is exploited due to the poor quality of the groundwater in the confined aquifer

560 below, caused notably by the generalized presence of brackish water and the occasional

561 occurrence of methane. The upper aquifer supplies several municipalities including the

562 City of Trois-Rivières. Finally, along the north shore of Lake St-Pierre, the most common

563 aquifer is type 2. The marine clay plain is considered an aquitard that confines aquifers

564 (glacial till and/or the Ordovician rocks) that are heavily mineralized or contain natural

565 gas accumulations.

566 Several local conceptual models prepared during the study are summarized in a

567 cross-section shown in Figure 11 that illustrates the typical geologic and

568 hydrostratigraphic units observed in southwest Mauricie. The upper panel is a geological

569 cross-section showing the distribution of Quaternary deposits and bedrock, and is based

570 on the 3D model. The lower panel displays a profile along the same section that identifies

571 the major hydrostratigraphic units and groundwater flow lines from the conceptual

572 hydrogeological model. The trace of cross-section A-A' is shown as a dashed line on

573 Figure 10. It starts in the Rivière du Loup valley near St-Alexis-des-Monts in the

574 northwest and runs eastward across the Saint-Narcisse Moraine near Charette, and

575 crosses Trois-Rivières towards the southeast. This profile was selected to reflect the main

576 hydrogeological contexts recognized in the region. While the elevation of the bedrock

577 surface and the terrain are both accurately depicted in the cross-section, some geological

578 and hydrogeological elements have been simplified to represent typical subsurface

579 characteristics in the study area. In other words, while the units and conditions illustrated 
580 on this cross-section are factual, they do not necessarily occur at the location of the 581 section.

582

583

584

585

586

587

588

589

590

591

592

593

594

595

596

597

598

599

600

601

602

603

604

605

606

607

608

The northwest segment of the cross-section shows typical hydrogeological conditions in the Laurentian Hills. The surficial sediment cover is generally thin, and valleys formed along bedrock depressions are commonly floored by coarse permeable sediments that are locally overlain by fine-grained marine/estuarine sediments. Confined aquifers are locally present below the Champlain Sea sediments in valleys lying at the maximum marine limit. The Precambrian bedrock underlying the surficial sediment cover includes igneous/metamorphic rocks with no primary porosity and very low fracture porosity. It is considered as an aquifer since water flows through it, but the capacity of the unit to yield an appreciable amount of groundwater ultimately depends on the interconnections of the fracture network, which tends to increase near the fault zones. In the northern part of the region, wells in bedrock commonly yield sufficient amounts of water for domestic supply, but sometimes have to be drilled to depths exceeding 40 metres.

Figure 11. Cross-section illustrating the typical geologic and hydrostratigraphic units encountered in southwest Mauricie. The trace of cross-section A-A' is shown as a dashed line on Figure 10.

Along the edge of the Laurentian Hills, the St-Narcisse morainic complex has hydrogeological conditions conducive for groundwater extraction. The moraine and associated glaciofluvial deposits on both its proximal and distal boundaries contain a group of aquifers that generally are poorly connected, but nonetheless connected through low-permeability glacial sediments or bedrock. The municipalities of Notre-Dame-duMont-Carmel and St-Paulin both extract groundwater from this unit. The Charette segment of the morainic complex has a similar hydrogeological potential, with an unconfined upper aquifer and a confined lower aquifer, both of which are not utilized. A series of depressions above the St-Cuthbert fault are filled by sand and gravel that may contain productive aquifers bounded by the marine clay aquitard. These depressions have not yet been tested or exploited for a municipal water supply. Even though the 
609 hydrogeological potential of the St-Cuthbert fault area remains untested, it likely plays a

610 key role in the regional flow system by intercepting groundwater flowing from the

611 Precambrian Hills and redirecting groundwater into glacial sand and gravel aquifers in

612 the adjacent Piedmont.

613 In the clay plain, the sediment cover is very thick but is almost exclusively

614 composed of very fine-grained marine mud (silty clay) with very low permeability. The

615 underlying till unit is more permeable than the Paleozoic bedrock by an order of

616 magnitude, but is still not considered an aquifer. Groundwater within the sedimentary

617 rocks below the Quaternary deposits is generally brackish. Because the rivers flowing

618 across the plain tend to be deeply entrenched, the extent of alluvial aquifers is limited.

619 However, the paleo-deltas of the Maskinongé and Yamachiche rivers are large enough to

620 contain significant groundwater supplies, and are used for a potable water supply by the

621 towns of St-Édouard-de-Maskinongé, Ste-Ursule, St-Alexis-des-Monts, St-Élie-de-

622 Caxton, Charette and St-Mathieu-du-Parc. Municipalities that are too far from the deltas

623 are supplied by a private aqueduct network operated by the Régie d'Aqueduc de Grand-

624 Pré, which pumps water from wells in glacial sand and gravel aquifers near St-Boniface.

625 The cross-section ends in the St-Maurice River paleo-delta sandy aquifers (Figure

626 11). This large deltaic system was built at the mouth of the valley during regression of the

627 Champlain Sea and subsequent Lake Lampsilis. The delta overlies either marine clays or

628 older Quaternary deposits. At St-Boniface and St-Étienne (upstream on the left bank), the

629 deltaic deposits contain an unconfined aquifer which caps the stratigraphic sequence, but

630 is too thin to supply large volumes of groundwater. In some areas though, where thicker

631 well-sorted sands occur, commonly in narrow erosional channels cut in the underlying

632 clay, there may be sufficient water supply for municipalities. In the Trois-Rivières

633 (downstream right bank) and Cap-de-la-Madeleine (downstream left bank) sectors,

634 significant thickening of the surficial sand cover makes the aquifer much more

635 productive. The St-Maurice River is deeply entrenched into its former delta, cutting

636 through even the upper till layer and pre-LGM Quaternary units. This creates

637 groundwater resurgences along the river. The City of Trois-Rivières pumps water from

638 the surficial sand deposits on both sides of the St-Maurice. The sedimentary rocks 
639 underlying the Quaternary deposits are moderately permeable, but the water contained in

640 the shale unit is mineralized and only used in a few geothermal applications.

\section{Discussion and conclusion}

\section{$3 D$ model}

As a result of its complex Quaternary history, the Mauricie region contains

644 significant granular aquifers, such as the paleodelta of the St. Maurice and Yamachiche

645 rivers, the Saint-Narcisse morainic complex and the high sandy terraces formed during

646 Champlain Sea regression. These aquifers had been partially investigated through local

647 hydrogeological studies conducted by municipalities. New fieldwork was undertaken to

648 supplement existing data and to build a coherent hydrostratigraphical model presenting

649 the stratigraphy and architecture of surficial deposits. Taking into account the reliability

650 ratings, surfaces representing the upper and lower contacts of geological formations were

651 modeled by cokriging. The result is a 3D model with seven layers representing the

652 surficial deposits of the Mauricie region, from the surface of the bedrock to the upper

653 littoral and deltaic sands. The total thickness of the sediments varies from zero, on rock

654 outcrops, to $150 \mathrm{~m}$ under the City of Trois-Rivières.

The 3D hydrostratigraphical model has helped refine our understanding of

656 regional aquifers, particularly the thickness, distribution and sequence of surficial

657 deposits in the valleys, along the St. Cuthbert Fault, under the Saint-Narcisse morainic

658 complex and in the paleodelta of the Saint-Maurice River. New, unexploited aquifers

659 have been identified north of the City of Trois-Rivières, around the Saint-Narcisse

660 morainic complex and along the St. Cuthbert Fault. The deposits of the St. Cuthbert Fault

661 are confined aquifers resulting from the deposition of granular sediments into a series of

662 bedrock depressions observed along the axis of the fault. These aquifers, as well as

663 confined aquifers beneath the marine clay plain, are only known indirectly through the

664 interpretation of geophysical surveys, such as seismic reflection profiling. Additional

665 drilling is required to determine the grain size distributions of the deposits to assess

666 aquifer potential. 


\section{Regional stratigraphy}

668

669

670

671

673

674

675

676

677

678

679

680

The results of the 3D model is consistent with the regional stratigraphy proposed by Gadd and Karrow (1959), Denis (1972), and Occhietti (1982). However, the modelling helped to further clarify the regional hydrostratigraphic framework, notably the topography of the bedrock surface, the subsurface extent of pre-LGM Quaternary sands, and the architecture of post-Champlain Sea deposits.

The pre-LGM Vieilles Forges sands were identified under the marine clay layer in borehole FE-02-11. This is the first drillhole that records the presence of this unit east of the St. Maurice River, and this allows us to better assess the extent of this regional unit. It is possible that some wells of the City of Trois-Rivières draw their water from this formation, rather than from the post-Champlain upper sands. Additional drilling (with dating) would be necessary to validate the extension of pre-LGM deposits north of TroisRivières. The permeability of these older deposits and the quality of the water they contain remain difficult to assess at a regional scale, as well as the hydraulic links between the upper sand aquifer and the bedrock.

Facies encountered in drilling along the Saint-Narcisse morainic complex vary widely. In general, the upper layer consists of coarse-grained sediments, from sand to cobbles and boulders, and is associated with ice retreat from the terminal moraine. This material generally lies above groundwater table and is too coarse to form a reservoir, but it contributes to the overall recharge of the surrounding aquifers. Multiple stratigraphic wells drilled in the center of the Saint-Narcisse Moraine showed the presence of a layer of fine-grained sediments or diamicton (till) at the base, confirming that the material was emplaced in a marine environment during a re-advance of the ice sheet. Although the permeability of this unit is lower than the overlying coarse-grained material, it cannot be considered as an aquitard due to its higher proportion of fine sand. However, a sandy aquifer confined below the marine fine-grained sediments was observed in some borings. For example, an aquifer contained in $20 \mathrm{~m}$ of medium sand, was discovered when drilling borehole FE-09-11 in the village of Sainte-Angèle-de-Prémont. This deposit should be investigated further, given its positive aquifer characteristics. 
The aquifer formed by the upper sands of the Trois-Rivières area is composed of a mixture of marine and lacustrine sands (littoral and deltaic), as well as sands associated with the paleodelta of the Saint-Maurice River. The unit rests on impermeable marine sediments on both sides of the river, but the thickness of the clay aquitard is much more variable on the west bank. The aquifer is highly stratified and encompasses many facies. Differentiating depositional environments based on grain size characteristics has been attempted, but did not achieve much success. In terms of thickness and grain size, the western deltaic zone shows a greater aquifer potential than the eastern zone, and our observations show that the upper sand in the northern part of the city has larger than expected thicknesses.

This study has highlighted yet again the major hydrogeological potential of the Champlain Sea deltas in the St-Lawrence Valley (for example, see Fagnan et al., 1998 for the Portneuf delta). Those deltaic constructions were emplaced as laterally continuous and thick units in a postglacial sea where sediment supply as well as accommodation space were elevated. They were later dissected by the post-glacial incision caused by the

711 glacial isostatic rebound. Similar contexts can be found all along the axis of the St-

712 Lawrence River, particularly at the mouth of its left bank tributaries which were fed by

713 abundant meltwaters and sediments derived from the receding Laurentide Ice Sheet.

Also highlighted were the few spatially disconnected buried valley aquifers 715 around the St-Narcisse Moraine, showing the highly dynamic nature of the depositional

716 process during this event. Similar buried aquifers can most likely be found close to the 717 moraine outside the study area.

\section{Acknowledgements}

This work is part of the Groundwater Knowledge Acquisition Program (PACES)

720 of the Quebec Ministry of the Environment (MDDELCC). It was conducted in

721 collaboration with a regional council of elected officials (CRÉ Mauricie), regional

722 municipalities (MRC Maskinongé), the city of Trois-Rivières, the Geological Survey of

723 Canada and watershed agencies. The authors would like to acknowledge the Minivibe

724 seismic profiling carried by André Pugin and Susan Pullan of the Geological Survey of 
725 Canada. We would also like to thank the municipal officials, the local residents and the

726 following persons for their collaboration: Myrabelle Chicoine, Isabelle Lessard, Alain

727 Rouleau, Ali Assani, Pierre-André Bordeleau, Francis Clément, Précillia Descoteaux,

728 Sophie Côté, Éric Dubois, Brian Bélisle, Philippe Davignon, Fannie Fortier-Fradette,

729 Lise Lamarche, Harold Vigneault, Marc-André Carrier, Miroslav Nastev, Claude Hébert,

730 François Hardy, René Lefebvre, Jean-Marc Ballard and Xavier Mallet.

\section{$731 \quad$ References}

732 Besré, F., and S. Occhietti. 1990. Les Varves de Deschaillons, les Rythmites du Saint733 Maurice et les Rythmites de Leclercville, Pléistocène supérieur, vallée du Saint734 Laurent, Québec. Geographie physique et Quaternaire 44 (2): 181-198.

735

Bolduc, A.M. 1999a. Géologie des formations superficielles: région de Shawinigan, Québec. Ottawa. Geological Survey of Canada. Map 1:50 000.

Bolduc, A.M. 1999b. Géologie des formations superficielles, région de Trois-Rivières, Québec. Ottawa. Geological Survey of Canada. Map 1:50 000.

Chesnaux, R., Lambert, M., Walter, J., Fillastre, U., Hay, M., Rouleau, A., Daigneault, R., Moisan, A., and D. Germaneau. 2011. Building a geodatabase for mapping hydrogeological features and 3D modeling of groundwater systems: Application to the Saguenay-Lac-St-Jean region, Canada. Computers \& Geosciences 37: 18701882.

Clark, T.H., and Y. Globensky. 1976. Rapport géologique RG-164 : Région de TroisRivières. Ministère des Richesses Naturelles : Direction générale des mines. Rapport et document cartographique.

Clet, M., and S. Occhietti. 1996. La sous-séquence des sédiments de Saint-Pierre rythmites du Saint-Maurice - Sables des Vieilles-Forges, Pléistocène supérieur, vallée du Saint-Laurent, Québec. Geographie physique et Quaternaire 50 (3): 287310. 
751 Denis, R. 1972. Géologie du quaternaire de la région de Saint-Gabriel-de-Brandon (moitié est), comtés Maskinongé, Berthier et Saint-Maurice : rapport préliminaire. Québec : Ministère des richesses naturelles, Direction générale des mines, Service de l'exploration géologique, Map.

Denis, R. 1974. Late Quaternary geology and geomorphology in the Lake Maskinongé area, Québec. PhD Thesis, University of Uppsala, 125 pp.

Fagnan, N., Michaud, Y., Lefebvre, R., Boisvert, E., Parent, M., Martel, R., Paradis, D., and D. Larose-Charette. 1998. Cartographie hydrogéologique régionale du piémont laurentien dans la MRC de Portneuf : hydrostratigraphie et piézométrie des aquifères granulaires de surface. Geological Survey of Canada, Open File 3664b, 1 sheet, doi:10.4095/210071.

Ferland, P., and S. Occhietti. 1990. Révision du stratotype des Sédiments de Saint-Pierre et implications stratigraphiques, vallée du Saint-Laurent, Québec. Geographie physique et Quaternaire 44 (2): 147-158.

Gadd, N.R., and P.F. Karrow. 1959. Surficial geology of Trois-Rivières: Saint-Maurice, Champlain, Maskinongé and Nicolet Counties, Québec. Geological Survey of Canada, 54-1959, map.

Globensky, Y. 1987. Géologie des Basses-Terres du Saint-Laurent. Ministère de l'Énergie et des Ressources du Québec, 63 pp.

Hardy, F. and M. Lamothe. 1997. Quaternary basin analysis using infrared stimulated luminescence on borehole cores and cuttings. Quaternary Science Reviews (Quaternary Geochronology), 16: 417-426.

Lamarche, L. 2005. Histoire géologique Holocène du lac Saint-Pierre et de ses ancêtres. Master's thesis, Université du Québec à Montréal, 225 pp.

McCormack, R. 1983. Étude hydrogéologique : Rive nord du Saint-Laurent. Québec: Ministère de 1'Environnement, Service des eaux souterraines. Map, 1:200 000. 
777 Nadeau, L., and P. Brouillette. 1995. Carte structurale de la région de Trois-Rivières SNRC 31I: Province de Grenville, Québec. Ottawa \& Québec: Commission géologique du Canada \& Centre géoscientifique de Québec. Map.

Occhietti, S. 1980. Le Quaternaire de la région de Trois-Rivières - Shawinigan, Québec : contribution à la paléogéographie de la vallée moyenne du St-Laurent et corrélations stratigraphiques. Montréal, Presses de l'Université du Québec, 230 pp.

783

784

785

786

787

788

789

790

791

792

793

794

Occhietti, S. 1982. Synthèse lithostratigraphique et paléoenvironnements du Quaternaire au Québec méridional. Géographie physique et Quaternaire 36 (1-2): 15-49.

Occhietti, S. 2007. The Saint-Narcisse morainic complex and early Younger Dryas events on the southeastern margin of the Laurentide Ice Sheet. Geographie physique et Quaternaire, 61 (2): 89-117.

Parent, M. and S. Occhietti. 1988. Late Wisconsinan deglaciation and Champlain Sea invasion in the St. Lawrence Valley, Québec. Géographie physique et Quaternaire, 42 (3): 215-246.

Parent, M. and S. Occhietti. 1999. Late Wisconsinan deglaciation and glacial lake development in the Appalachians of southeastern Québec. Géographie physique et Quaternaire, 53 (1): 117-135.

Prévôt, J.M. 1972. Carte hydrogéologique des Basses Terres du St-Laurent: Ministère des Richesses naturelles du Québec, Carte 1748.

Ross, M., Parent, M., and R. Lefebvre. 2005. 3D geologic framework models for regional hydrogeology and land-use management: a case study from a Quaternary basin of southwestern Québec, Canada. Hydrogeology Journal 13: 690-707. 


\section{Figure Captions}

800 Figure 1. Location and digital elevation model of the study area. The four main regional

801 hydrogeologic contexts are shown: the Laurentian Hills, Saint-Narcisse morainic

802 complex, Marine clay plain and paleodelta of the St. Maurice River.

803 Figure 2. Quaternary geology and location of the new geophysical surveys and boreholes.

804 The location of the existing boreholes and wells (5 386) used to build the model are not

805 shown. See Table 2 for a detailed description of the units.

806 Figure 3. Flowchart of the GIS operations used to model the top surface of each

807 hydrogeological unit.

808 Figure 4. Total thickness of Quaternary deposits. The thickest deposits, reaching $150 \mathrm{~m}$,

809 are in the western part of the City of Trois-Rivières.

810 Figure 5.3D model of Quaternary deposits. The model consists of six layers representing

811 the main hydrogeological units observed above bedrock in the study area. The six layers

812 represent the Pleistocene sediments (pre-LGM) (a), LGM and post-Younger Dryas tills

813 (b), glaciofluvial sediments (c), marine silt and clay (d), St. Narcisse morainic complex

814 (e) and littoral, deltaic and alluvial sediments (f).

815 Figure 6. Thickness grids (m) of Quaternary deposits.

816 Figure 7. Logs of selected boreholes with lithology and grain size. The locations of the

817 boreholes are shown in Figure 2.

818 Figure 8. High resolution seismic survey lines L1-2011 (a) and L7-9-2010 (b). The

819 profile interpretations are shown below the seismic profiles. See Figure 2 for location of

820 the seismic lines and Table 2 for a detailed description of the units.

821 Figure 9. High resolution seismic survey lines L3-2010 (a) and L3-2011 (b). The profile

822 interpretations are shown below the seismic profiles. See Figure 2 for location of the

823 seismic lines and Table 2 for a detailed description of the units. 
824 Figure 10. Aquifer types of the Mauricie region based on the architecture of the 825 hydrostratigraphic units.

826 Figure 11. Cross-section illustrating the typical geologic and hydrostratigraphic units

827 encountered in southwest Mauricie. The trace of cross-section A-A' is shown as a dashed 828 line on Figure 10.

829 
Table 1. Sources of hydrogeological data.

Sources

Number of

wells/boreholes

Hydrogeological Information System (Québec)

2311

Ministry of Transportation (Québec)

Hydrogeological studies by consultants

Municipal databases

312

Hydrogeological studies from the Ministry of the Environment (Québec)

Private databases

Système d'Information Géoscientifique, Pétrolier et Gazier (SIGPEG)

164 
Table 2. Quaternary stratigraphy of the study area.

\begin{tabular}{|c|c|c|c|}
\hline $\begin{array}{c}\text { Age } \\
\mathrm{Ka}\end{array}$ & Code & Formation & Lithology \\
\hline \multirow{6}{*}{11.7} & $\mathbf{O}$ & Organic deposits & Peat mainly \\
\hline & $\mathbf{E}$ & Aeolian sediments & Fine sand \\
\hline & At & Terraced alluvial sediments & Sand, sandy silt and gravelly sand \\
\hline & Ap & Alluvial sediments - Floodplain & Sand, sandy silt, gravelly sand and gravel \\
\hline & Ld & $\begin{array}{l}\text { Lacustrine sediments - Deltaic } \\
\text { facies }\end{array}$ & $\begin{array}{l}\text { Sand, gravely sand and well-sorted gravel, deposited at } \\
\text { the mouth of rivers flowing into Lake Lampsilis }\end{array}$ \\
\hline & Lb & $\begin{array}{l}\text { Lacustrine sediments - Littoral } \\
\text { and nearshore facies of Lake } \\
\text { Lampsilis }\end{array}$ & $\begin{array}{l}\text { Sand, silt and gravelly sand and gravel deposited along or } \\
\text { near Lake Lampsilis shorelines }\end{array}$ \\
\hline \multirow{9}{*}{75} & $\mathrm{Cg}$ & $\begin{array}{l}\text { Mass-wasting deposits - } \\
\text { Landslides }\end{array}$ & $\begin{array}{l}\text { Mainly silt, clay and sand reworked by landslides in } \\
\text { Champlain Sea sediments }\end{array}$ \\
\hline & Md & Marine sediments - Deltaic facies & $\begin{array}{l}\text { Sand, gravelly sand and gravel, stratified and well sorted, } \\
\text { deposited at the mouth of rivers flowing into the } \\
\text { Champlain Sea, locally including prodeltaic silty sands }\end{array}$ \\
\hline & Mb & $\begin{array}{l}\text { Marine sediments }- \text { Littoral } \\
\text { facies }\end{array}$ & $\begin{array}{l}\text { Sand, sandy silt, gravelly sand and gravel deposited along } \\
\text { or near Champlain Sea shorelines }\end{array}$ \\
\hline & Ma & $\begin{array}{l}\text { Marine sediments - Offshore } \\
\text { facies }\end{array}$ & $\begin{array}{l}\text { Clayey silt and silty clay deposited in Champlain Sea } \\
\text { basins }\end{array}$ \\
\hline & GxT & $\begin{array}{l}\text { Glaciofluvial and glacial } \\
\text { sediments of the St-Narcisse }\end{array}$ & $\begin{array}{l}\text { Sand and gravel, till or diamicton deposited at the ice } \\
\text { front during the Younger Dryas readvance }\end{array}$ \\
\hline & Go & $\begin{array}{l}\text { Glaciofluvial sediments - } \\
\text { subaerial outwash facies }\end{array}$ & $\begin{array}{l}\text { Sand and gravel, well stratified and sorted, forming } \\
\text { outwash plains locally pitted by kettles }\end{array}$ \\
\hline & Gs & $\begin{array}{l}\text { Glaciofluvial sediments - } \\
\text { Subaqueous outwash facies }\end{array}$ & $\begin{array}{l}\text { Mainly sand, minor silty sand or some gravel, deposited } \\
\text { at the mouth of sub-glacial tunnels entering in the } \\
\text { Champlain Sea }\end{array}$ \\
\hline & $\mathbf{G x}$ & $\begin{array}{l}\text { Glaciofluvial sediments - Ice- } \\
\text { contact facies }\end{array}$ & $\begin{array}{l}\text { Mainly sand and gravel, minor diamicton, forming eskers, } \\
\text { kames, delta-kames, ice-contact terraces or moraine } \\
\text { ridges }\end{array}$ \\
\hline & $\mathbf{T}$ & $\begin{array}{l}\text { Glacial sediments - Gentilly Till, } \\
\text { Yamachiche Diamicton }\end{array}$ & $\begin{array}{l}\text { Sandy silt diamicton, compact gray matrix, deposited by } \\
\text { the ice sheet and forming continuous blanket and } \\
\text { discontinuous veneer, locally reworked by waves and } \\
\text { currents along Champlain Sea shorelines }\end{array}$ \\
\hline 115 & $\mathbf{Q}$ & \multicolumn{2}{|c|}{$\begin{array}{l}\text { Undifferentiated older Quaternary deposits: sand (Lotbinière Sand, St-Pierre sand, Vieilles } \\
\text { Forges sand), rhythmites (Deschaillons varves, St-Maurice rythmites), diamictons (Lévrard } \\
\text { till, Bécancour Till) }\end{array}$} \\
\hline 128 & $\mathbf{Q}$ & $\begin{array}{l}\text { Glacial sediments - Bécancour } \\
\text { till }\end{array}$ & $\begin{array}{l}\text { Diamicton characterized by a brick red color inherited } \\
\text { from the erosion of red shales }\end{array}$ \\
\hline
\end{tabular}


Table 3. Hydraulic properties of the regional granular aquifers: hydraulic conductivity (K), transmissivity (T), saturated thickness (b), coefficient of storage $(\mathrm{S})$ and specific capacity $(\mathrm{Q} / \mathrm{s})$. See location map in Figure 1.

\begin{tabular}{|c|c|c|c|c|c|c|}
\hline Granular aquifers & & $\mathbf{K}(\mathbf{m} / \mathbf{s})$ & $\mathbf{T}\left(\mathrm{m}^{2} / \mathbf{d}\right)$ & b (m) & $\mathbf{S}$ & $\mathbf{Q} / \mathbf{s}\left(\mathbf{m}^{3} / \mathbf{d} / \mathbf{m}\right)$ \\
\hline \multicolumn{7}{|l|}{ Laurentian Hills and piedmont } \\
\hline \multirow[t]{2}{*}{ Valley bottoms } & Unconfined & $5.11 \mathrm{E}-04$ & 436.6 & 8.0 & $2.00 \mathrm{E}-02$ & 288.0 \\
\hline & Confined & $3.36 \mathrm{E}-04$ & 772.8 & 4.3 & $1.41 \mathrm{E}-03$ & 287.2 \\
\hline \multirow[t]{2}{*}{ Paleodelta and terraces of the Maskinongé River } & Unconfined & $5.16 \mathrm{E}-03$ & 287.0 & 23.2 & - & 208.6 \\
\hline & Confined & $1.24 \mathrm{E}-04$ & 260.2 & 11.2 & $1.03 \mathrm{E}-03$ & 62.0 \\
\hline \multirow[t]{2}{*}{ Paleodelta and terraces of the Yamachiche River } & Unconfined & $5.03 \mathrm{E}-04$ & 685.5 & 8.4 & 7.70E-02 & 240.5 \\
\hline & Confined & $8.30 \mathrm{E}-05$ & 172.8 & 24.1 & $6.10 \mathrm{E}-04$ & 99.4 \\
\hline \multicolumn{7}{|l|}{ Saint-Narcisse morainic complex } \\
\hline \multirow[t]{2}{*}{ Notre-Dame-du-Mont-Carmel } & Unconfined & - & 20.8 & - & - & 166.3 \\
\hline & Confined & $2.75 \mathrm{E}-04$ & 457.4 & 19.3 & 3.33E-04 & 172.6 \\
\hline \multirow[t]{2}{*}{ Charette } & Unconfined & - & - & 6.7 & - & 165.5 \\
\hline & Confined & $1.06 \mathrm{E}-04$ & 30.5 & 3.1 & - & 34.6 \\
\hline \multirow[t]{2}{*}{ Sainte-Angèle-de-Prémont and Saint-Paulin } & Unconfined & $9.68 \mathrm{E}-05$ & 987.5 & 26.3 & $3.21 \mathrm{E}-02$ & 362.2 \\
\hline & Confined & $5.69 \mathrm{E}-04$ & 752.0 & 13.5 & 4.31E-04 & 186.3 \\
\hline Glaciofluvial deposits of the St.-Cuthbert Fault* & Confined & - & - & - & - & - \\
\hline Glaciofluvial deposits underlying the marine plain* & Confined & $4.08 \mathrm{E}-06$ & 0.8 & 2.1 & - & 1.6 \\
\hline Littoral deposits of Lake Lampsilis & Unconfined & - & - & - & - & - \\
\hline \multicolumn{7}{|l|}{ Paleodelta of the Saint-Mauricie River } \\
\hline Saint-Boniface & Unconfined & - & - & - & - & 223.8 \\
\hline Shawinigan & Unconfined & $2.85 \mathrm{E}-04$ & 563.8 & 8.4 & - & 366.7 \\
\hline Saint-Étienne-des-Grès & Unconfined & $5.67 \mathrm{E}-04$ & 267.7 & 5.0 & $1.19 \mathrm{E}-01$ & 173.4 \\
\hline Notre-Dame-du-Mont-Carmel & Unconfined & $5.56 \mathrm{E}-05$ & 149.6 & 6.8 & $1.00 \mathrm{E}-04$ & 146.1 \\
\hline Pointe-du-Lac (Trois-Rivières) and Yamachiche & Unconfined & $1.55 \mathrm{E}-05$ & 199.5 & 9.0 & $8.90 \mathrm{E}-02$ & 203.6 \\
\hline \multirow[t]{2}{*}{ Trois-Rivières and Trois-Rivières-Ouest } & Unconfined & 2.79E-04 & 874.6 & 24.4 & 2.05E-01 & 231.7 \\
\hline & Confined $* *$ & - & 604.8 & - & - & 70.8 \\
\hline Saint-Louis-de-France (Trois-Rivières) & Unconfined & $7.70 \mathrm{E}-05$ & 49.2 & 15.3 & $1.37 \mathrm{E}-01$ & 55.0 \\
\hline \multirow[t]{2}{*}{ Cap-de-la-Madeleine (Trois-Rivières) } & Unconfined & $3.36 \mathrm{E}-04$ & 352.7 & 8.1 & $1.22 \mathrm{E}-01$ & 206.4 \\
\hline & Confined* & $1.64 \mathrm{E}-04$ & 86.4 & 6.1 & - & 29.2 \\
\hline
\end{tabular}

* Untapped confined aquifer ** Sables des Vieilles Forges 
Table 4. Hydraulic properties of the regional fractured rock aquifers: hydraulic conductivity (K), transmissivity (T), saturated thickness (b), coefficient of storage (S) and specific capacity $(\mathrm{Q} / \mathrm{s})$. See location map in Figure 1.

\begin{tabular}{|c|c|c|c|c|c|c|}
\hline \multicolumn{2}{|c|}{ Fractured rock aquifers } & $\mathbf{K}(\mathbf{m} / \mathbf{s})$ & $\mathbf{T}\left(\mathbf{m}^{2} / \mathbf{d}\right)$ & b (m) & $\mathbf{S}$ & $\mathbf{Q} / \mathbf{s}\left(\mathbf{m}^{3} / \mathbf{d} / \mathbf{m}\right)$ \\
\hline \multicolumn{7}{|c|}{ Laurentian Hills and piedmont (Canadian Shield) } \\
\hline \multirow[t]{2}{*}{ Mékinac-Taureau domain } & Unconfined & $2.15 \mathrm{E}-07$ & - & 61.9 & - & 1.7 \\
\hline & Confined & $7.41 \mathrm{E}-07$ & - & - & - & - \\
\hline \multirow[t]{2}{*}{ Morin terrane } & Unconfined & 6.67E-09 & 9.7 & 71.0 & - & 3.2 \\
\hline & Confined & $7.70 \mathrm{E}-05$ & 79.2 & 36.1 & - & 44.6 \\
\hline \multirow[t]{2}{*}{ Intrusive suites } & Unconfined & 7.78E-06 & - & 20.3 & - & 6.5 \\
\hline & Confined & - & - & - & - & - \\
\hline \multicolumn{7}{|l|}{ St. Lawrence Platform } \\
\hline Sandstone & Confined & - & - & - & - & - \\
\hline Limestone & Confined & $2.14 \mathrm{E}-06$ & 0.2 & 1.5 & - & 0.9 \\
\hline Shale & Confined* & $9.14 \mathrm{E}-07$ & - & - & - & - \\
\hline
\end{tabular}

* Untapped confined aquifer 


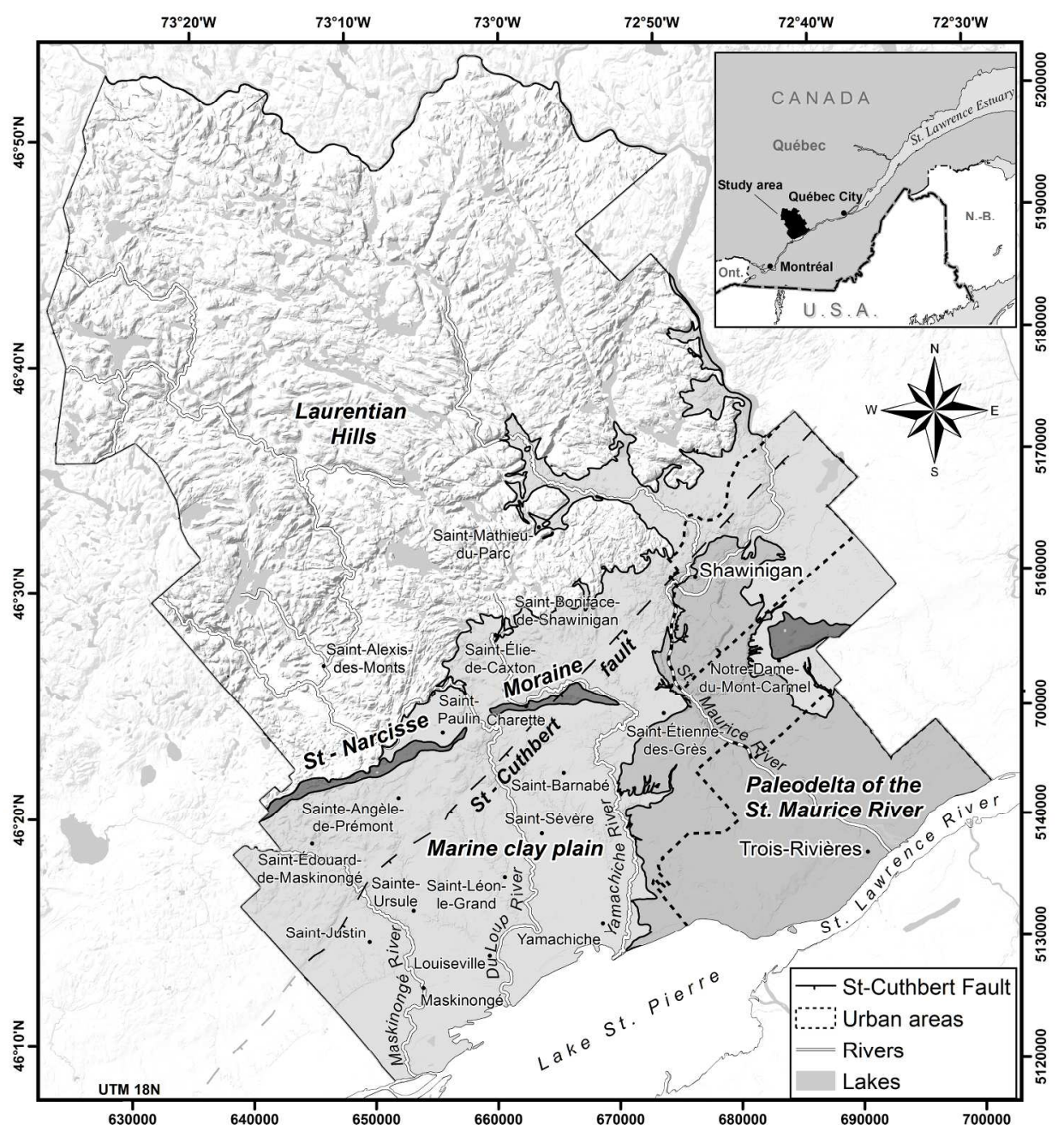

Figure 1. Location and digital elevation model of the study area. The four main regional hydrogeologic contexts are shown: the Laurentian Hills, Saint-Narcisse morainic complex, Marine clay plain and paleodelta of the St. Maurice River.

Figure 1

$228 \times 242 \mathrm{~mm}(300 \times 300 \mathrm{DPI})$ 


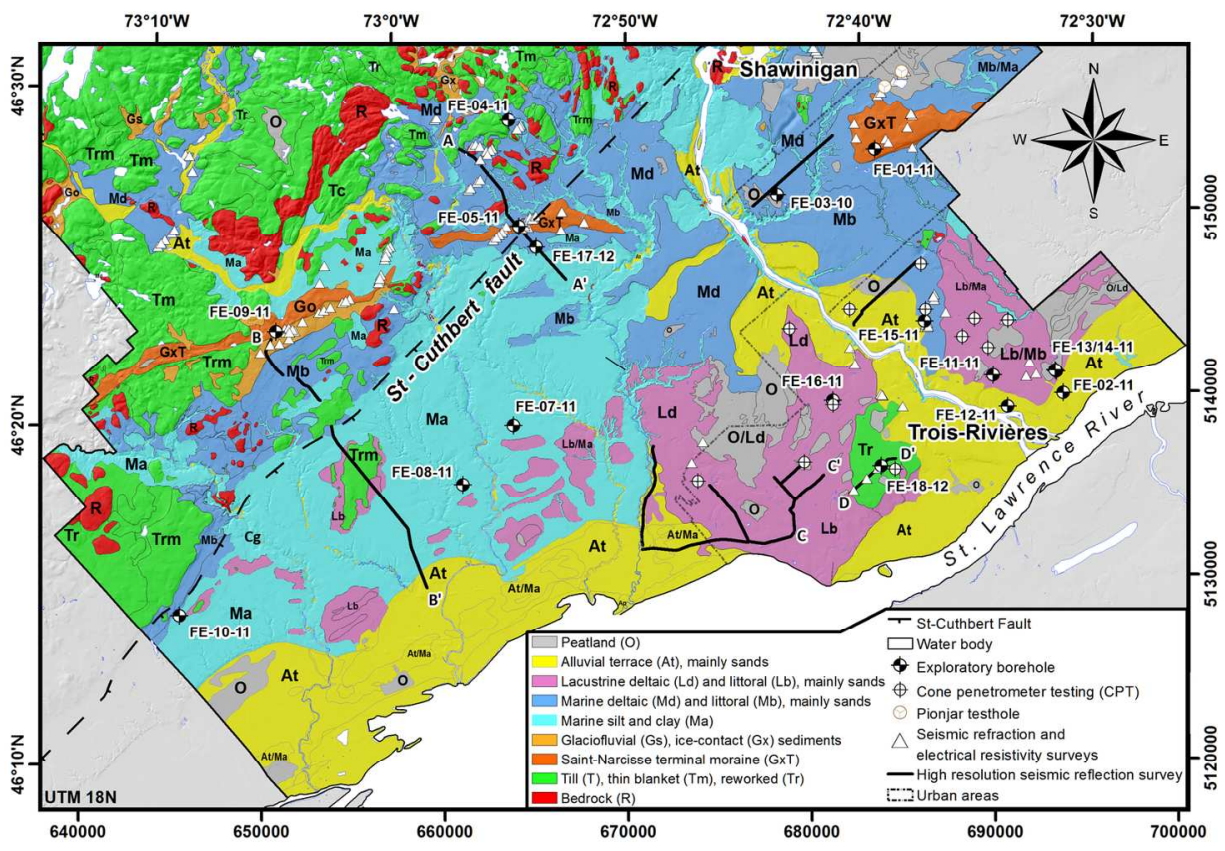

Figure 2. Quaternary geology and location of the new geophysical surveys and boreholes. The location of the existing boreholes and wells ( 5386 ) used to build the model are not shown. See Table 2 for a detailed description of the units.

Figure 2

$152 \times 107 \mathrm{~mm}(300 \times 300$ DPI $)$ 


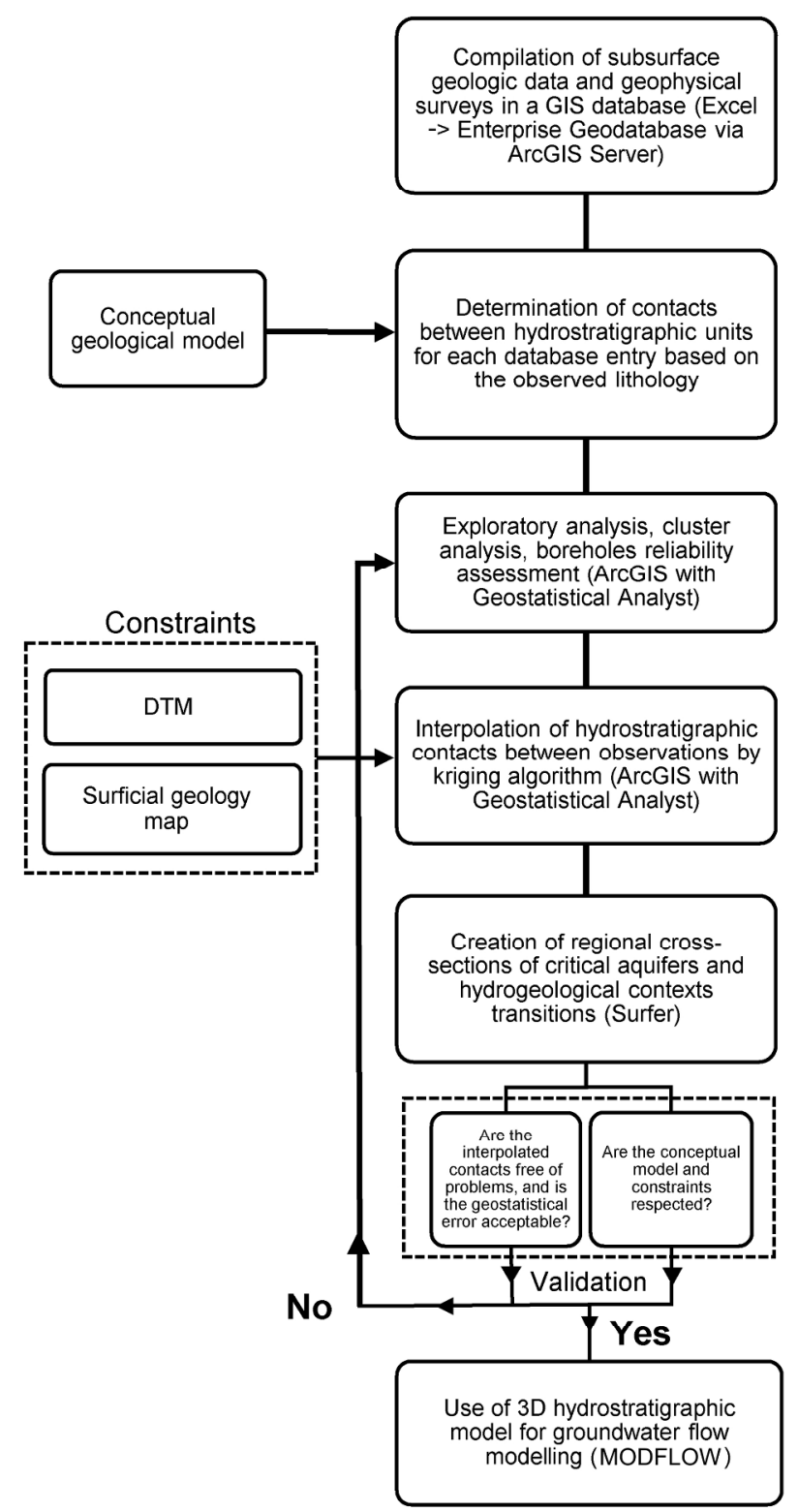

Figure 3. Flowchart of the GIS operations used to model the top surface of each hydrogeological unit. Figure 3

$160 \times 290 \mathrm{~mm}(300 \times 300 \mathrm{DPI})$ 


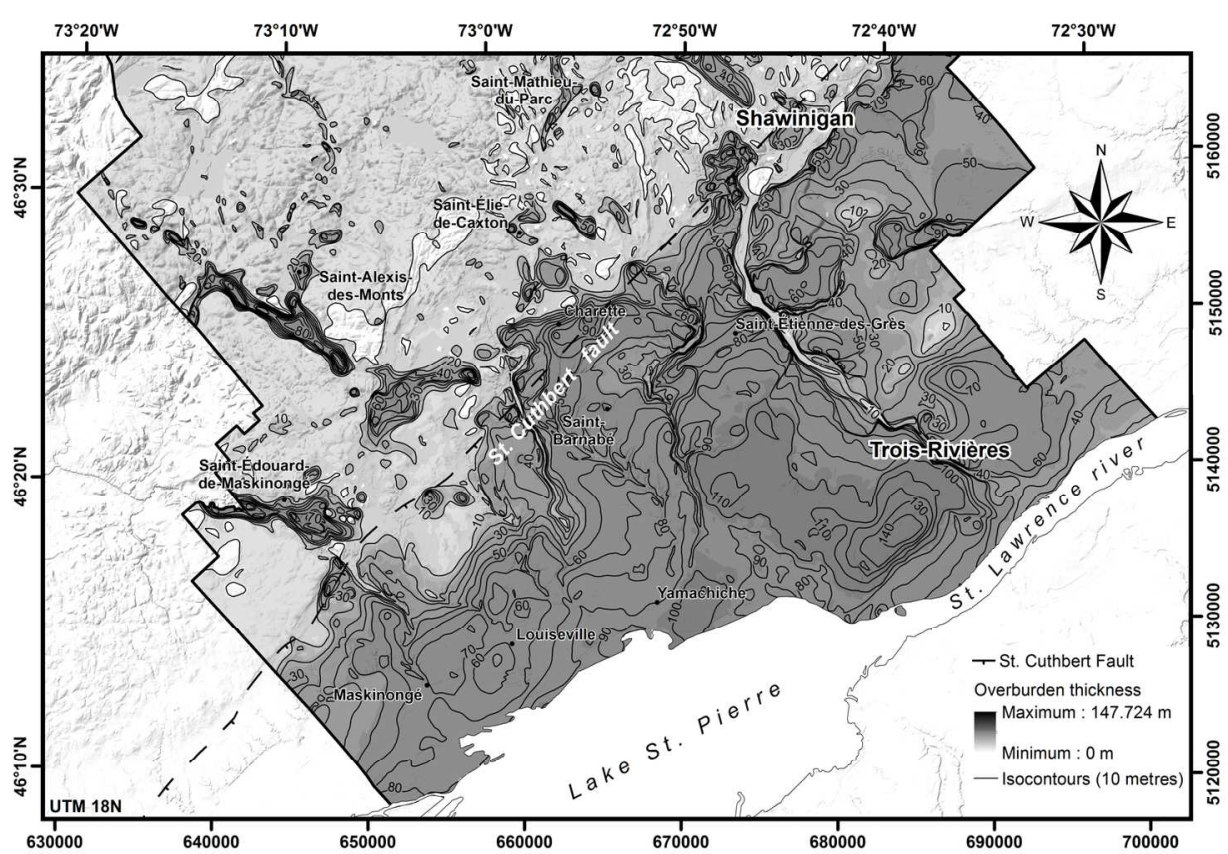

Figure 4. Total thickness of Quaternary deposits. The thickest deposits, reaching $150 \mathrm{~m}$, are in the western part of the City of Trois-Rivières.

Figure 4

$152 \times 107 \mathrm{~mm}(300 \times 300 \mathrm{DPI})$ 


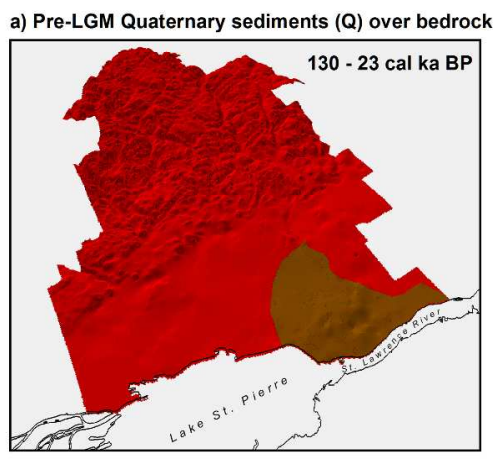

c) Glaciofluvial scdiments (Go, Gs)

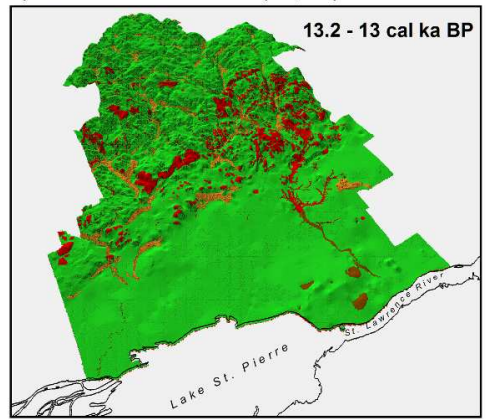

e) St-Narcisse morainic complex (Gx, GxT)

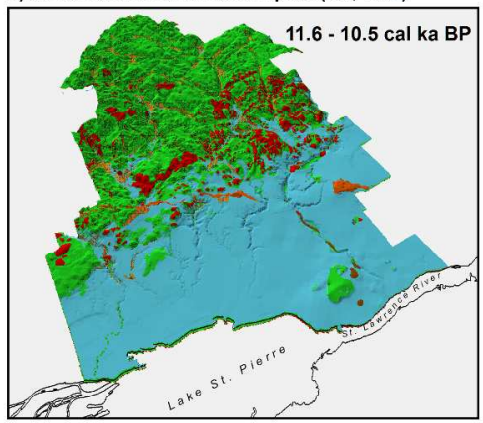

b) LGM and post-Younger Dryas tills (T)

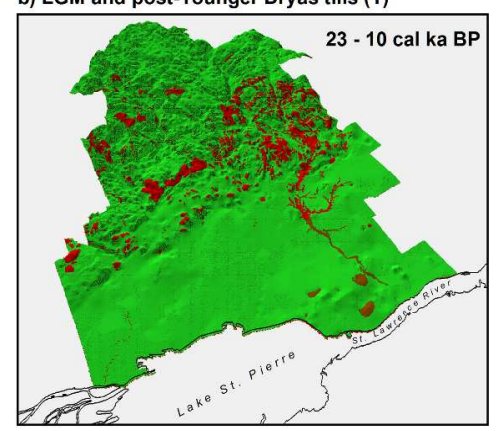

d) Marine silt and clay - Champlain Sea (Ma)

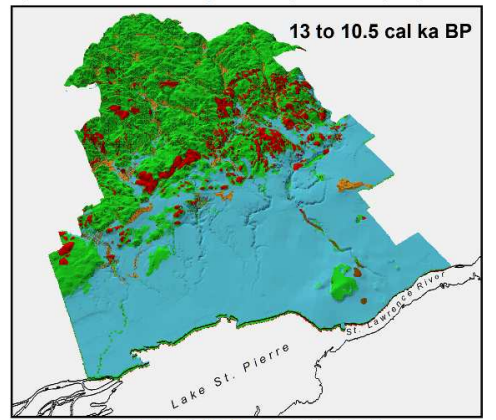

f) Littoral, deltaic and alluvial sediments

$(\mathrm{Mb}, \mathrm{Md}, \mathrm{Lb}, \mathrm{Ld}, \mathrm{At})$

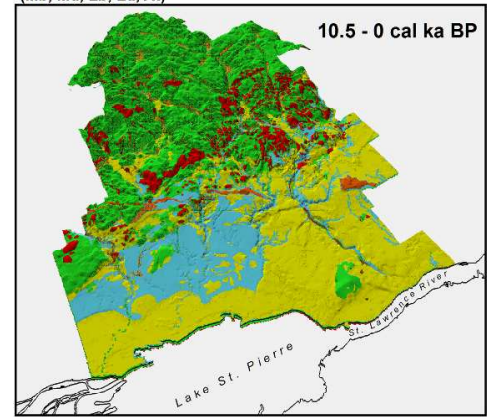

Figure 5. 3D model of Quaternary deposits. The model consists of six layers representing the main hydrogeological units observed above bedrock in the study area. The six layers represent the Pleistocene sediments (pre-LGM) (a), LGM and post-Younger Dryas tills (b), glaciofluvial sediments (c), marine silt and clay (d), St. Narcisse morainic complex (e) and littoral, deltaic and alluvial sediments (f).

Figure 5

$279 \times 361 \mathrm{~mm}(300 \times 300 \mathrm{DPI})$ 

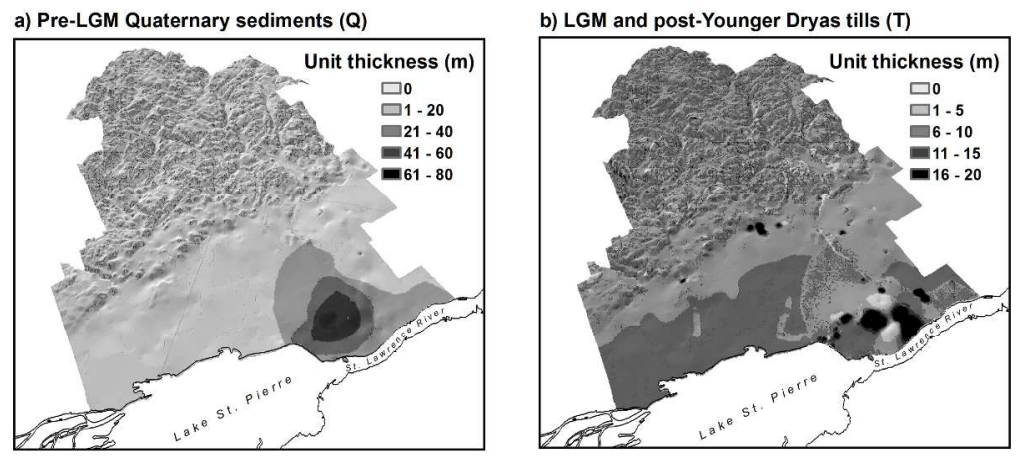

c) Glaciofluvial sediments (G)

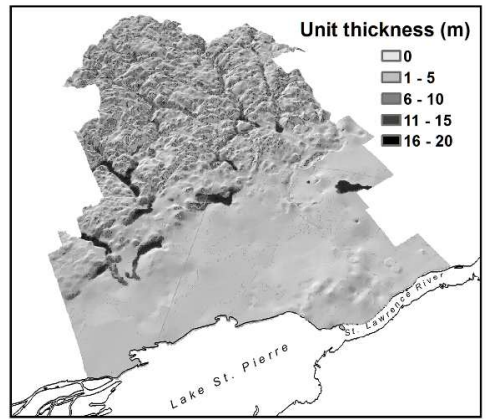

e) St-Narcisse morainic complex (Gx, GxT)
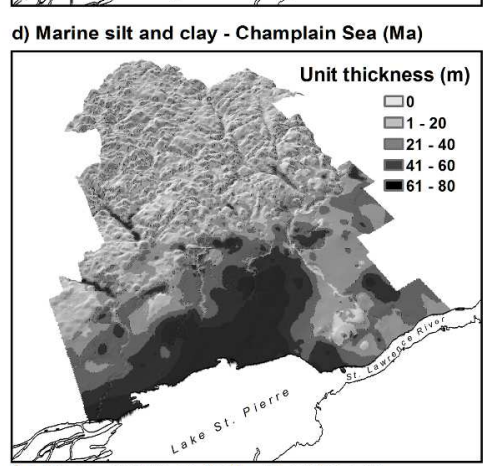

f) Littoral, deltaic and alluvial sediments
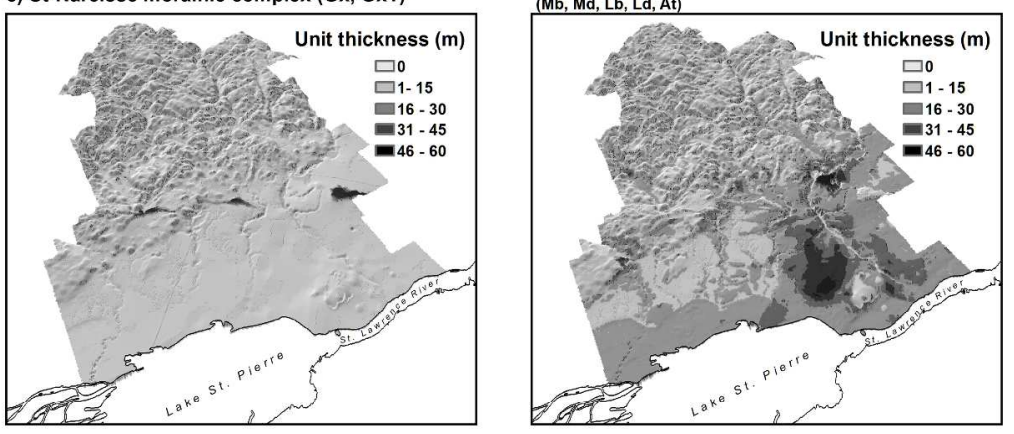

Figure 6. Thickness grids ( $m$ ) of Quaternary deposits.

Figure 6

$279 \times 361 \mathrm{~mm}$ (300 x 300 DPI) 


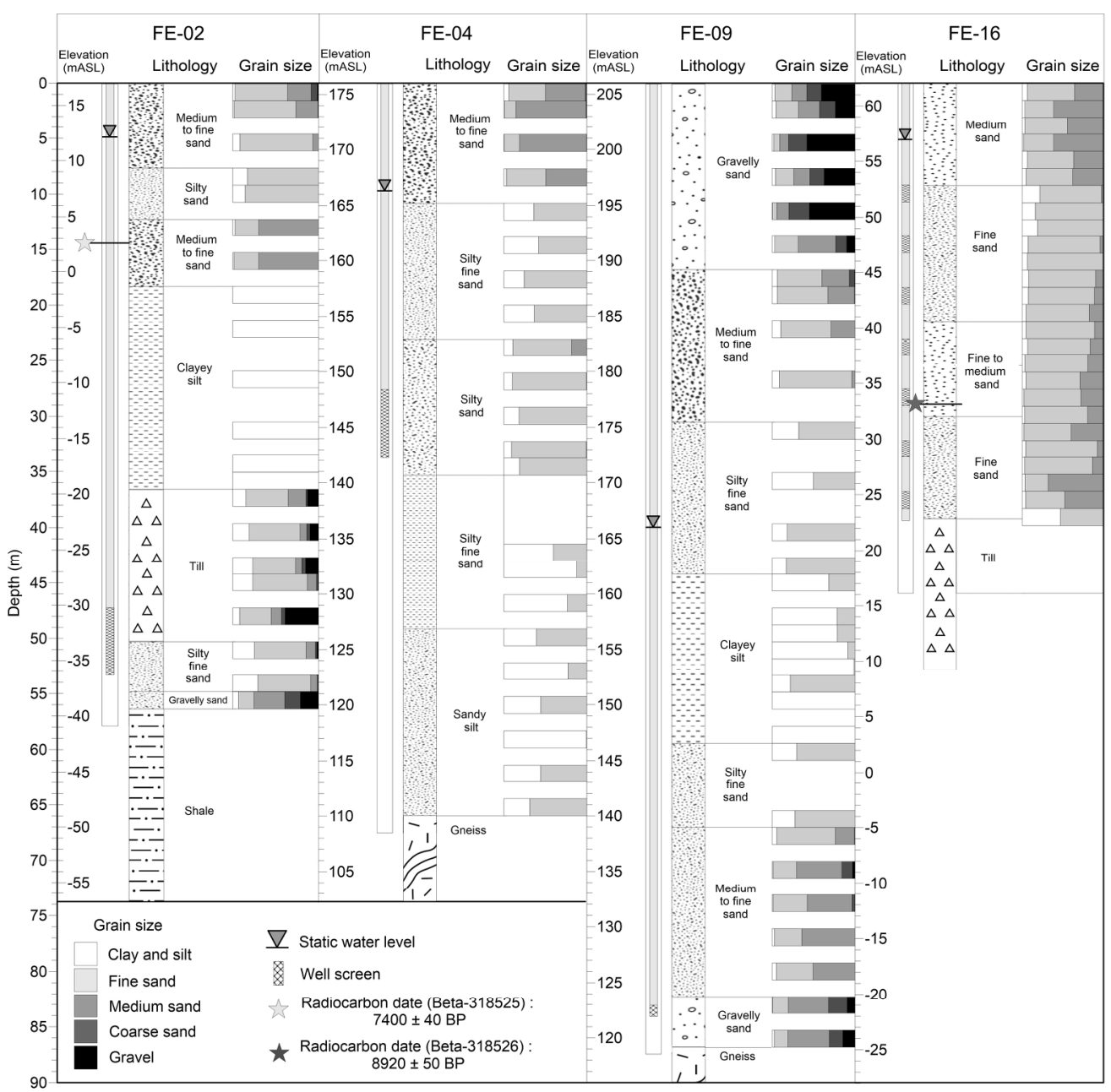

Figure 7. Logs of selected boreholes with lithology and grain size. The locations of the boreholes are shown in Figure 2.

Figure 7

$200 \times 199 \mathrm{~mm}(300 \times 300$ DPI $)$ 

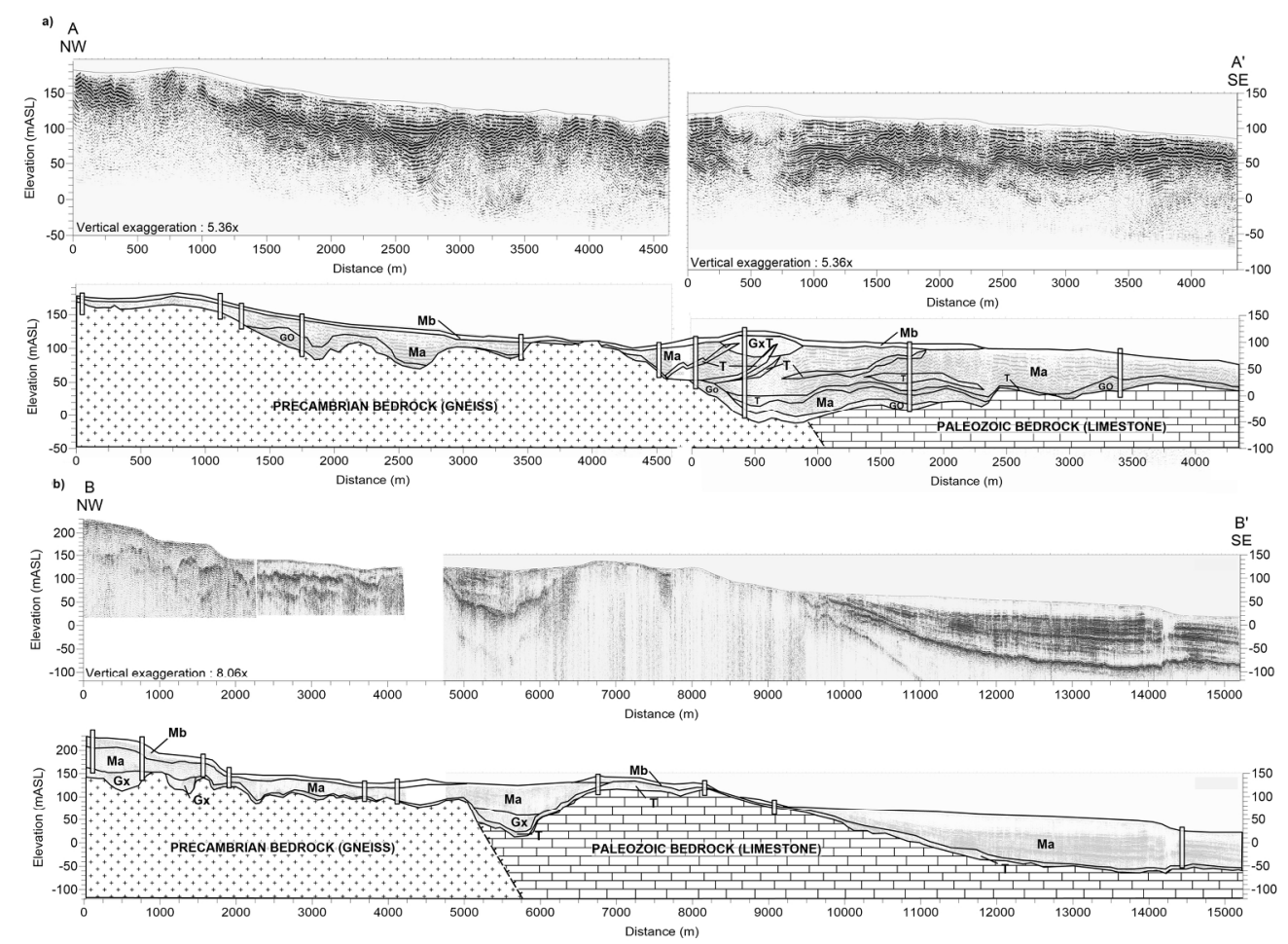

Figure 8. High resolution seismic survey lines L1-2011 (a) and L7-9-2010 (b). The profile interpretations are shown below the seismic profiles. See Figure 2 for location of the seismic lines and Table 2 for a detailed description of the units.

Figure 8

$205 \times 150 \mathrm{~mm}(300 \times 300$ DPI $)$ 

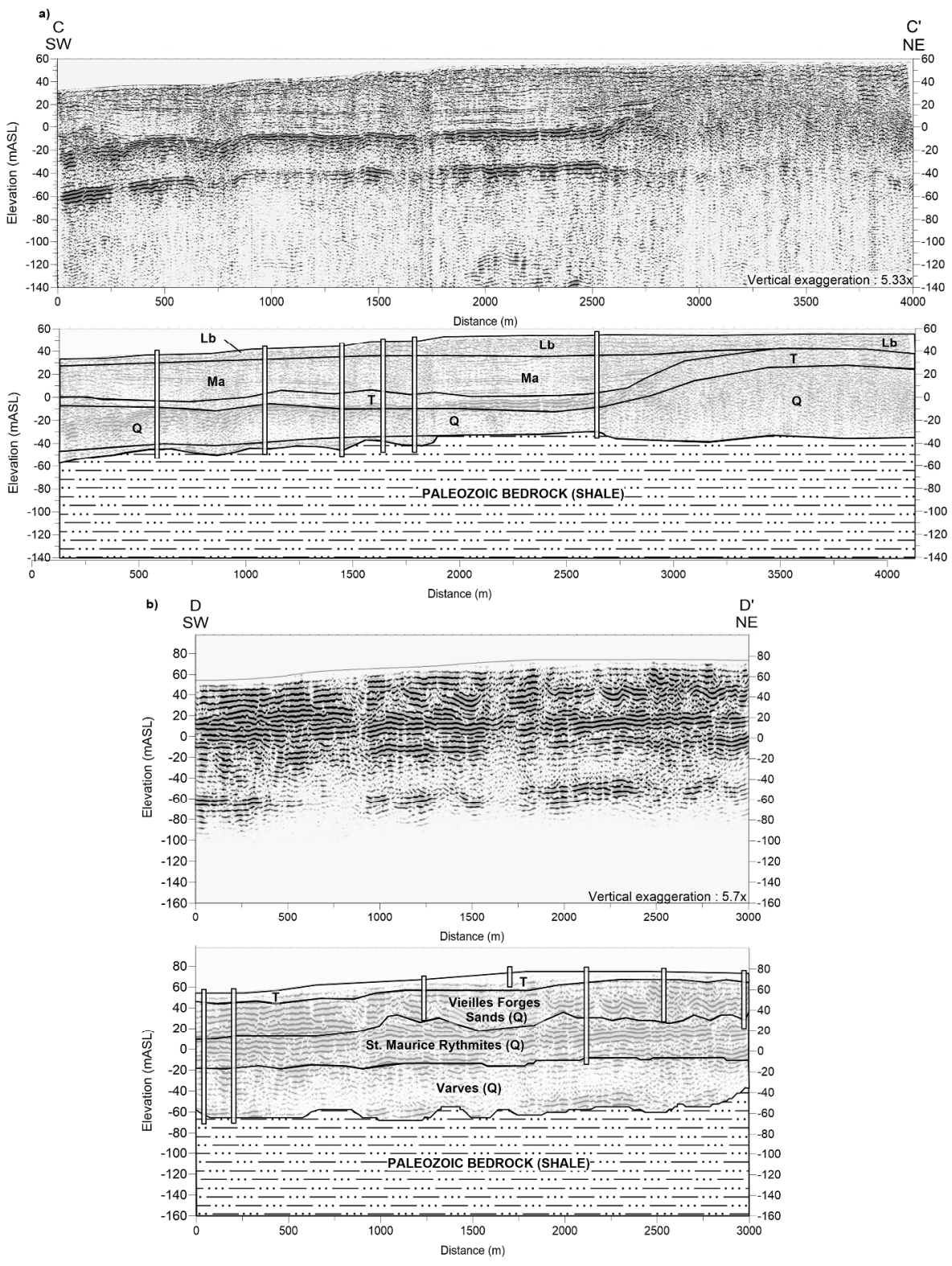

Figure 9. High resolution seismic survey lines L3-2010 (a) and L3-2011 (b). The profile interpretations are shown below the seismic profiles. See Figure 2 for location of the seismic lines and Table 2 for a detailed description of the units.

Figure 9

$271 \times 348 \mathrm{~mm}(300 \times 300$ DPI) 


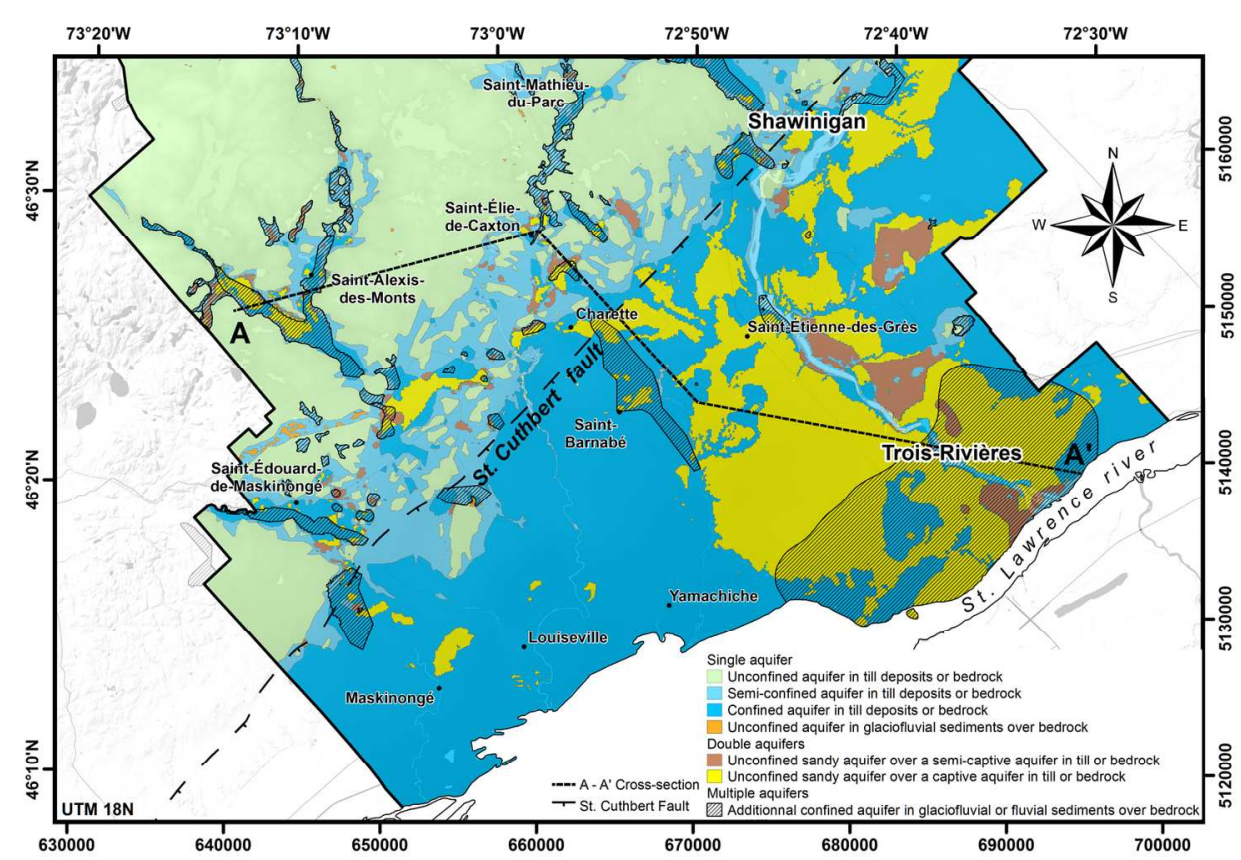

Figure 10. Aquifer types of the Mauricie region based on the architecture of the hydrostratigraphic units. Figure 10 $152 \times 107 \mathrm{~mm}(300 \times 300 \mathrm{DPI})$ 

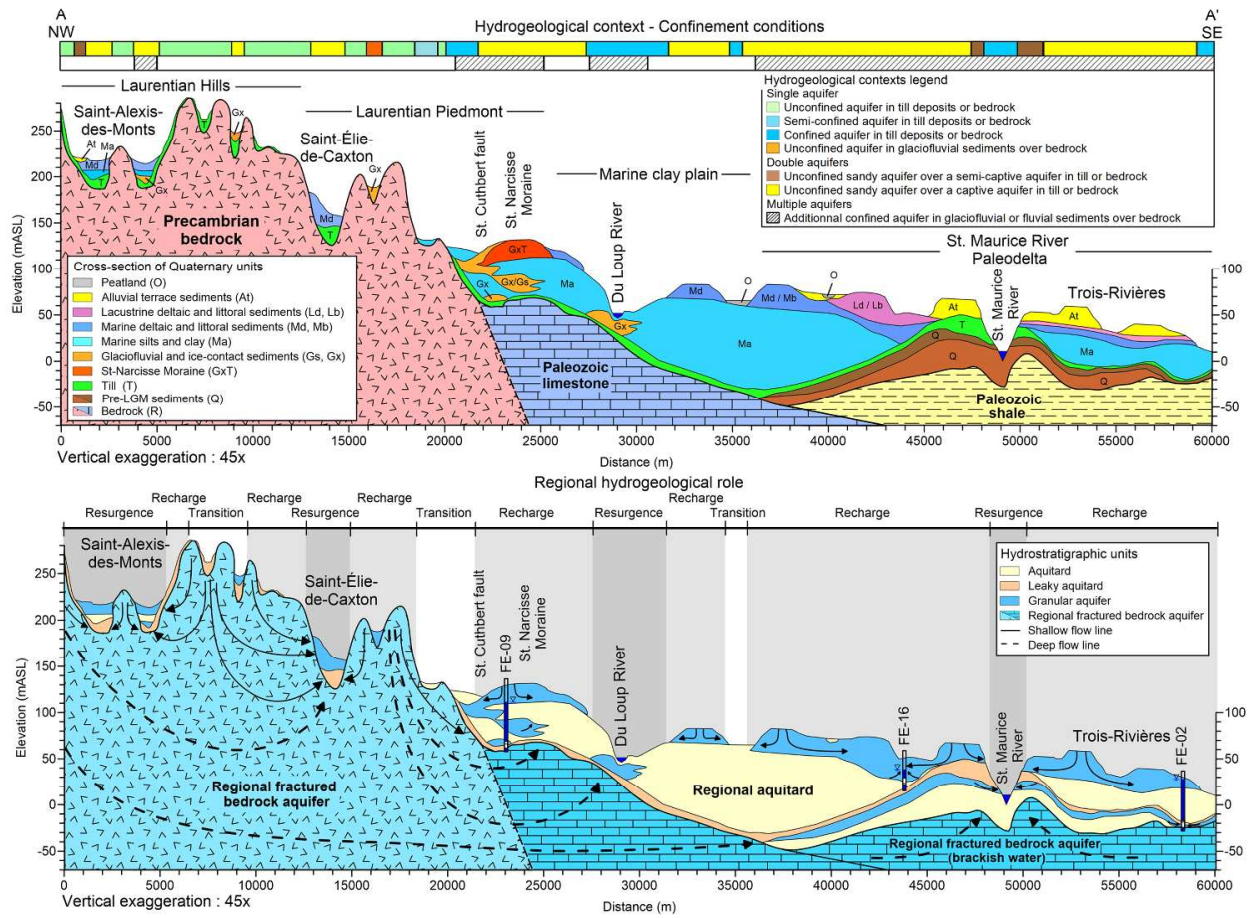

Figure 11. Cross-section illustrating the typical geologic and hydrostratigraphic units encountered in southwest Mauricie. The trace of cross-section A-A' is shown as a dashed line on Figure 10. Figure 11

$223 \times 176 \mathrm{~mm}(300 \times 300 \mathrm{DPI})$ 